\title{
Two-Dimensional Layered Nanomaterial-Based Electrochemical Biosensors for Detecting Microbial Toxins
}

\author{
Zhuheng $\mathrm{Li}^{1,2,+}{ }^{,}$Xiaotong $\mathrm{Li}^{2,+}$, Minghong Jian ${ }^{2}$, Girma Selale Geleta ${ }^{2,3, *}$ and \\ Zhenxin Wang $2, * \mathbb{D}$ \\ 1 Jilin Provincial Institute of Education, Changchun 130022, China; lizhuheng@126.com \\ 2 State Key Laboratory of Electroanalytical Chemistry, Changchun Institute of Applied Chemistry, Chinese \\ Academy of Science, Changchun 130022, China; lixiaotong@ciac.ac.cn (X.L.); mhjian@ciac.ac.cn (M.J.) \\ 3 Department of Chemistry, College of Natural Sciences, Jimma University, Jimma 378, Ethiopia \\ * Correspondence: ggirma245@gmail.com (G.S.G.); wangzx@ciac.ac.cn (Z.W.); \\ Tel.: +251-(0471)-111252 (G.S.G.); +86-(0431)-85262243 (Z.W.) \\ + These authors contributed equally.
}

Received: 4 November 2019; Accepted: 27 December 2019; Published: 31 December 2019

\begin{abstract}
Toxin detection is an important issue in numerous fields, such as agriculture/food safety, environmental monitoring, and homeland security. During the past two decades, nanotechnology has been extensively used to develop various biosensors for achieving fast, sensitive, selective and on-site analysis of toxins. In particular, the two dimensional layered (2D) nanomaterials (such as graphene and transition metal dichalcogenides (TMDs)) and their nanocomposites have been employed as label and/or biosensing transducers to construct electrochemical biosensors for cost-effective detection of toxins with high sensitivity and specificity. This is because the 2D nanomaterials have good electrical conductivity and a large surface area with plenty of active groups for conjugating 2D nanomaterials with the antibodies and/or aptamers of the targeted toxins. Herein, we summarize recent developments in the application of 2D nanomaterial-based electrochemical biosensors for detecting toxins with a particular focus on microbial toxins including bacterial toxins, fungal toxins and algal toxins. The integration of 2D nanomaterials with some existing antibody/aptamer technologies into electrochemical biosensors has led to an unprecedented impact on improving the assaying performance of microbial toxins, and has shown great promise in public health and environmental protection.
\end{abstract}

Keywords: two dimensional layered nanomaterials; electrochemical biosensors; microbial toxin detection; antibodies; aptamers

Key Contribution: This review updates the construction strategies of electrochemical biosensors such as immunosensors and aptasensors for cost-effective determination of microbial toxins with high sensitivity given by rapidly developing two dimensional layered (2D) nanomaterial-based labels and substrates. We summarize the roles of 2D nanomaterials and their nanocomposites in the configuration of electrochemical biosensors, as well as the advantages they provide to the analyses, and address the major challenges and perspectives of these electrochemical biosensors for future commercialization.

\section{Introduction}

Two-dimensional layered (2D) nanomaterial (e.g., graphene and its derivatives, transition metal dichalcogenides (TMDs) and other layered nanosheets)-based electrochemical signal amplifications 
have great potential for improving both the sensitivity and selectivity of electrochemical biosensors because of their unique physical, chemical, and electrical properties [1-21]. Graphene is a single layer of densely packed carbon atoms with a benzene-ring structure, and is the first known 2D layered nanomaterial [22]. The unique properties of graphene, including its exceptional mechanical strength [23], extremely large surface area $\left(2630 \mathrm{~m}^{2} / \mathrm{g}\right)$ [24], very high thermal conductivity in the range of $\sim 3080-5150 \mathrm{~W} \mathrm{mK}^{-1}$ [25], high conductivity [26], good charge carrier mobility [27], and wide potential window [28], endow it with great applicability in the development of biosensors, and, in particular, electrochemical biosensors [1-5,12,22-24,29]. In addition, based on the molar ratio of carbon to oxygen $(\mathrm{C} / \mathrm{O})$, graphene can be roughly divided into two categories, graphene oxide (GO) or reduced graphene oxide (rGO). It is demonstrated that rGO has better electrical conductivity than GO. Because pure graphene lacks an intrinsic band gap and is limited by chemical modification, there is an increasing interest in synthesizing graphene derivatives/nanocomposites and graphene-like 2D nanomaterials. Among the graphene-like 2D nanomaterials, TMDs (e.g., molybdenum disulfide $\left(\mathrm{MoS}_{2}\right)$ and molybdenum selenide $\left.\left(\mathrm{MoSe}_{2}\right)\right)$ show excellent physicochemical properties and remarkable biocompatibility, and also have significant attraction for the fabrication of electrochemical (bio)sensors $[6,7,9,14,21,29]$. Driven by their unprecedented properties, massive synthetic methods/protocols have been developed for preparing 2D nanomaterials and 2D nanomaterial composites, which involves both physical strategies and chemical approaches, such as dry mechanical exfoliation (e.g., Scotch tape), chemical (e.g., solution-based exfoliation, graphite oxide exfoliation/reduction) and/or electrochemical (oxidation/reduction and exfoliation) processes, chemical vapor deposition (CVD), chemical synthesis, thermal decomposition of SiC wafers and unzipping carbon nanotubes [26,30-43]. In this review, we will not describe the detailed synthetic methods/protocols mentioned above for synthesis of 2D nanomaterials, however, we suggest reading several recently published comprehensive review articles [40-45]. These methods of 2D nanomaterial preparation produce different forms of nanomaterials with a diversity of properties including mechanical, optical, electrical, chemical and biological properties. These diverse properties make 2D nanomaterials suitable for an extensive range of applications, such as drug delivery, in vitro and in vivo imaging, tissue engineering, biosensor construction, and energy conversion and storage $[39,43,46]$. For biosensor applications, 2D nanomaterials should be extensively characterized because their properties strongly dependent on their characteristics such as thickness or number of layers, morphology, chemical structure and surface functional groups.

Microbial toxins are the general term for a class of substances covering a broad range from small molecules to biomacromolecules (e.g., peptides and proteins), which are produced by living organisms including bacteria, fungus and algae [47-53]. They are widespread throughout the whole world, threatening the health and/or life of humans and livestock, and affecting domestic and international trade. For instance, aflatoxin B1 (AFB1, a kind of mycotoxin produced by fungi) has been defined as a group I carcinogen by the World Health Organization (WHO) [53]. Some microbial toxins can generate acute poisonous effects even at very low doses, and the co-occurrence of microbial toxins in nature may cause significantly additive and/or synergistic toxicity. In order to efficiently avoid potential hazards on public health and safety, it is important to precisely and reliably determine the toxins in practical samples from different sources. Liquid chromatography-based methods including high-performance liquid chromatography (HPLC) and high-performance liquid chromatography-tandem mass spectrometry (HPLC/MS/MS) are the gold standards for accurate analysis of toxins [54-59]. Although the HPLC-based methods have high reliability and accuracy, they typically require expensive laboratory facilities and instruments, complex pre-treatment processing of the sample and well-trained operators. These drawbacks strongly limit the application of HPLC-based methods in on-site detections of toxin. Various sensing systems such as surface plasmon resonance (SPR) biosensors, electrochemical biosensors, fluorescence biosensors, colorimetric assays, competitive enzyme-linked immunosorbent assay (ELISAs) and microfluidic immunoassay have been developed for analysis of toxins from different sources including clinical samples, foods, water and feeds [60-66]. Among these 
biosensing systems, electrochemical biosensors and biotransducers are more attractive because they offer several advantages such as high sensitivity, operational simplicity, relatively low cost, easily miniaturization and suitable on-site analysis [8,11-19,67-69]. These advantages make electrochemical biosensors/transducers of microbial toxins powerful tools in many areas including food, environmental and medical monitoring, disease diagnosis and anti-terrorism security. Owing to the large surface areas and excellent conductivities, the integration of 2D nanomaterials (e.g., graphene and TMDs) and their nanocomposites with electrochemical transducers has great potential to enhance the analytical performance of electrochemical biosensors for detection of toxins [8,11-19]. For example, since its birth, multiple research initiatives on graphene applied to electroanalytical chemistry have been launched worldwide, and analysts have been developing a plethora of different graphene-based electrochemical sensing platforms for detection of various targets including microbial toxins. Typically, these electrochemical biosensors comprise a graphene and/or a graphene derivative/nanocomposite-modified electrode as an electrochemical signal transduction element, and a biological recognition element (e.g., antibodies, aptamer and microbial cells). The signal from the biological recognition event is converted to a quantifiable electrical signal because the biological target is normally in close contact with the electrochemical signal transduction element through physical or chemical interactions (e.g., electrostatic interactions, $\pi-\pi$ interactions and covalent bonds). Because of their unique properties (e.g., large surface area and good conductivity), the detection performance of an electrochemical biosensor can be significantly improved by using the graphene and/or a graphene derivative/nanocomposite. Therefore, the scope of application of 2D nanomaterial-based electrochemical biosensors has been constantly expanding in the field of toxin detection. Some of these studies have been reviewed elsewhere with a focus on the fabrication and toxin detection of graphene-based electrochemical biosensors or as subclassifications in more generalized overviews of the nanomaterial-based electrochemical biosensors [8,11-19]. In this review, we will focus on the recent development of GO/rGO and/or $\mathrm{MoS}_{2} / \mathrm{MoSe}_{2}$-based electrochemical biosensors for the determination of various microbial toxins, such as bacterial toxins, fungal toxins and algal toxins, highlighting some of their current achievements, technical challenges/limitations and the future directions by means of a set of selected recent publications.

\section{Detection of Bacterial Toxins}

\subsection{Botulinum Neurotoxins}

The Botulinum neurotoxins (BoNTs), which are produced by Clostridium botulinum, an anaerobic bacterium, are among the most toxic of all naturally occurring substances [70-72]. Based on their molecular structures, BoNTs are categorized into seven serotypes (from A to G). They inhibit acetylcholine release from presynaptic nerve terminals at the neuro-muscular junction in both the central and peripheral nervous systems through cleavage of soluble N-ethylmaleimide-sensitive factor attachment protein receptors (SNAREs), resulting in flaccid muscle paralysis. BoNTs can cause the deadly disease, botulism, with a median lethal dose (LD50) of $1 \mathrm{ng}$ per kg bodyweight. Foods are easily contaminated by Clostridium botulinum during processing. Various (impedimetric, voltammetric and amperometric) electrochemical biosensors have been fabricated for BoNT detection [73-76]. In particular, electrochemical biosensors can achieve detection of this toxin in a fast and meticulous way, and they also provide a robust and cost-effective approach for real-time monitoring of BoNTs. Recently, 2D nanomaterial-based electrochemical biosensors have been applied to sensitively detect BoNTs in various samples including foods. For instance, Narayanan et al. constructed an electrochemical immunosensor of the BoNT serotype E (BoNT/E) by using graphene nanosheets-aryldiazonium salts as transducers [74]. The as-proposed immunosensor shows a low limit of detection (LOD, $5 \mathrm{pg} \mathrm{mL}^{-1}$ ) and can be employed for rapid detection of BoNT/E with a total analysis time of $65 \mathrm{~min}$. Chan et al. fabricated an electrochemical biosensor for ultrasensitive detection of BoNT serotype A light chain (BoNT-LcA) through immobilization of the SNAP-25-GFP (synaptosomal associated protein 25-green fluorescent protein) peptide substrate on the rGO modified gold electrode via 
a pyrenebutyric acid (PA) linker (as shown in Figure 1) [75]. In this case, PA was immobilized on the rGO surface through $\pi-\pi$ stacking. Subsequently, SNAP-25-GFP peptide reacted with PA via $\mathrm{N}$-(3-dimethylaminopropyl)-N'-ethylcarbodiimide hydrochloride/N-hydroxysulfosuccinimide (EDC/Sulfo-NHS) activation. After specific cleavage of SNAP-25-GFP by BoNT-LcA, the steric hindrance and electrostatic repulsion of SNAP-25-GFP decreased, resulting in an increase in the electrochemical signal. The amount of BoNT-LcA can be detected through the change of peak current of the electrochemical redox probe (ferricyanide, $\left[\mathrm{Fe}(\mathrm{CN})_{6}\right]^{3-/ 4-}(1: 1)$ ) by the differential pulse voltammetry (DPV) measurement. The as-fabricated electrochemical biosensor provides a relatively wide linear range $\left(1 \mathrm{pg} \mathrm{mL}^{-1}\right.$ to $\left.1 \mathrm{ng} \mathrm{mL}^{-1}\right)$ and a relatively low LOD $\left(8.6 \mathrm{pg} \mathrm{mL}^{-1}\right)$ for detection of BoNT-LcA because the rGO modified $\mathrm{Au}(\mathrm{rGO} / \mathrm{Au}$ ) electrode provides a robust and biocompatible platform with improved electron transfer capability and a large surface area for peptide immobilization. The feasibility of the as-fabricated biosensor is demonstrated by detection of BoNT-LcA in spiked milk samples. Afkhami et al. developed a gold nanoparticle-graphene-chitosan (Au NPs-Gr-Cs) nanocomposite-based impedimetric immunosensor for the detection of BoNT serotype A (BoNT/A) [76]. The Au NPs-Gr-Cs nanocomposite was used for the amplification of the electrochemical signal, and monoclonal anti-BoNT/A antibodies were conjugated on the Au NPs-Gr-Cs nanocomposite modified glassy carbon electrode (GCE). In the presence of BoNT/A, the immunocomplex formed on the as-prepared electrode surface, which acts as the inert electron and mass transfer blocking layer. Therefore, the diffusion of $\left[\mathrm{Fe}(\mathrm{CN})_{6}\right]^{3-/ 4-}$ is hindered, resulting in a decrease of the peak current. The Au NPs-Gr-Cs nanocomposite-based impedimetric immunosensor has an excellent linear range (from 0.27 to $268 \mathrm{pg} \mathrm{mL}^{-1}$ ) with a LOD of $0.11 \mathrm{pg} \mathrm{mL}^{-1}$, and is very suitable for routine analysis of BoNT/A in different matrices, such as serum and milk.

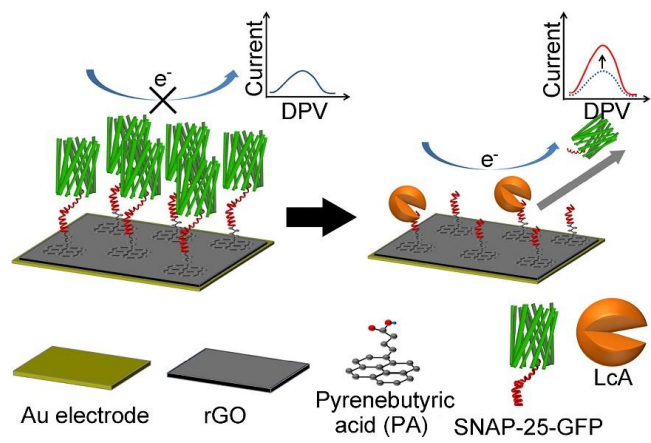

Figure 1. Schematic representation of the detection principle of the rGO based electrochemical biosensors (adapted from Chan et al. 2015 [75], Copyright 2015 Elsevier B.V. and reproduced with permission).

\subsection{Clostridium difficile Toxin $B$}

Clostridium difficile toxin A (Tcd A, $308 \mathrm{kDa}$ ) and toxin B (Tcd B, $270 \mathrm{kDa}$ ) are co-produced by Clostridium difficile (C. difficile). Tcd A is an enterotoxin responsible for tissue damage, while Tcd B is referred to as a potent cytotoxin [77-81]. In particular, the rapid and sensitive detection of Tcd B is very helpful for early diagnosis and efficient therapy because Tcd B is critical for virulence and is found in all clinically isolated pathogenic strains [79-85]. Using the advantages of GO, including the large surface area and good conductivity, Fang et al. developed a simple sandwich-assay type electrochemical immunosensor for improving the Tcd B detection sensitivity by using GO as a scaffold for the enhanced loading of horseradish peroxidase (HRP) and HRP-labeled secondary Tcd B antibody (as shown in Figure 2) [84]. The LOD $\left(0.7 \mathrm{pg} \mathrm{mL}^{-1}\right)$ of the sandwich-assay type electrochemical immunosensor is much lower than those of other current techniques including ELISA. In addition, the as-prepared electrochemical immunosensor was successfully employed to detect Tcd B in practical samples (e.g., real human stool), demonstrating that the immunosensor has promising potential in clinical applications. 


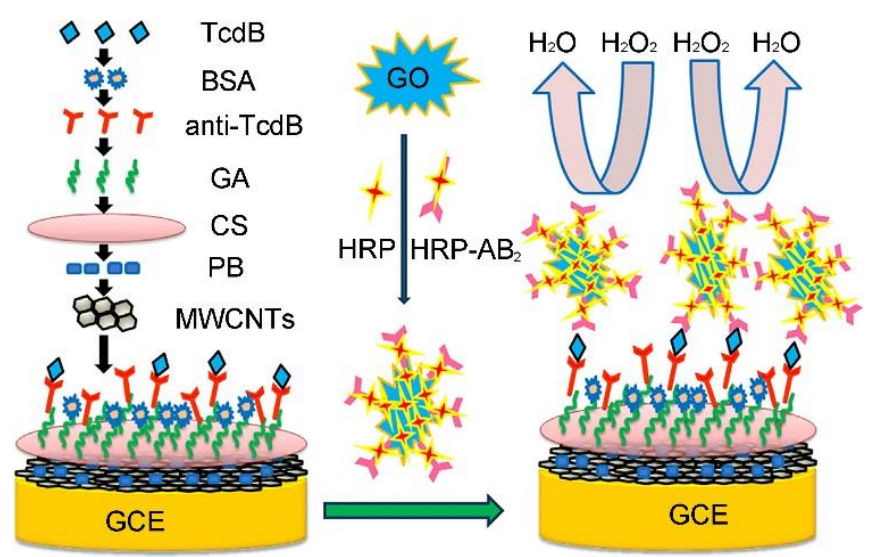

Figure 2. Schematic representation of the immunosensor array preparation and detection strategy by sandwich-type immunoassay of Tcd B. Here, Tcd B means C. difficile toxin B, BSA means bovine serum albumin, anti-Tcd B means anti-Tcd B antibody, HRP means horseradish peroxidase, HRP-Ab2 means HRP-labeled second anti-Tcd B antibody, GA means glutaraldehyde, CS means chitosan, PB means Prussian blue, MWCNTs means multi-walled carbon nanotube, GO means graphene oxide, and GCE means glassy carbon electrode (adapted from Fang et al. 2014 [84], Copyright 2013 Elsevier B.V. and reproduced with permission).

\subsection{Staphylococcal Enterotoxin B}

Among the toxins secreted by Staphylococcus aureus, the staphylococcal enterotoxin B (SEB) shows superantigenic properties in nature. SEB exposure can result in immunosuppression and serious food poisoning $[86,87]$. Therefore, it is important to develop a cost-effective, easy-to-use, rapid and sensitive method for real-time monitoring of a low concentration (less than $20 \mathrm{ng} \mathrm{kg}^{-1}$ (i.e., $\mathrm{LD}_{50}$ value)) of SEB in foods. Several graphene-based electrochemical biosensors have been developed for real-time detection of SEB in foods with a high sensitivity [88-91]. For instance, Sharma et al. reported on an electrochemical biosensor based on a rGO-chitosan-AuNPs-capturing antibody (rGR-Ch-AuNPs-CAb)-modified GCE for detecting SEB [88]. The rGR-Ch-AuNPs-CAb modified GCE shows remarkable detecting performance because it has a flat two-dimensional configuration and large surface area with plenty of active sites (i.e., functional groups). Using the as-proposed rGR-Ch-AuNPs-CAb-based electrochemical biosensor, $5 \mathrm{ng} \mathrm{mL}^{-1}$ SEB can be easily detected within $35 \mathrm{~min}$, which is much lower than the $\mathrm{LD}_{50}$ value of SEB. Very recently, Nodoushan et al. fabricated an electrochemical aptasensor for SEB detection by using a rGO and gold nano-urchins (AuNUs)-modified screen printed carbon electrode (SPCE) (as shown in Figure 3) [91]. The aptamer of SEB was attached on the electrode surface through hybridization with the immobilized single-stranded DNA probe on the surface of the AuNUs. Hematoxylin was used as the electrochemical signal generator. In the presence of SEB, the aptamer released from the electrode surface, resulting in an increase in the peak current of hematoxylin. Benefiting from the high conductivity of rGO and high surface area of AuNUs, a wide linear range from 5.0 to $500.0 \mathrm{fmol} \mathrm{L}^{-1}$ was achieved and the LOD was calculated as $0.21 \mathrm{fmol} \mathrm{L}^{-1}$. There is no significant difference between the results given by the commercial ELISA kit and the electrochemical aptasensor. In particular, the aptasensor shows better recovery rates and lower standard deviation than those of the commercial ELISA kit, which could be employed as a point-of-care (POC) device for assessing food samples. 


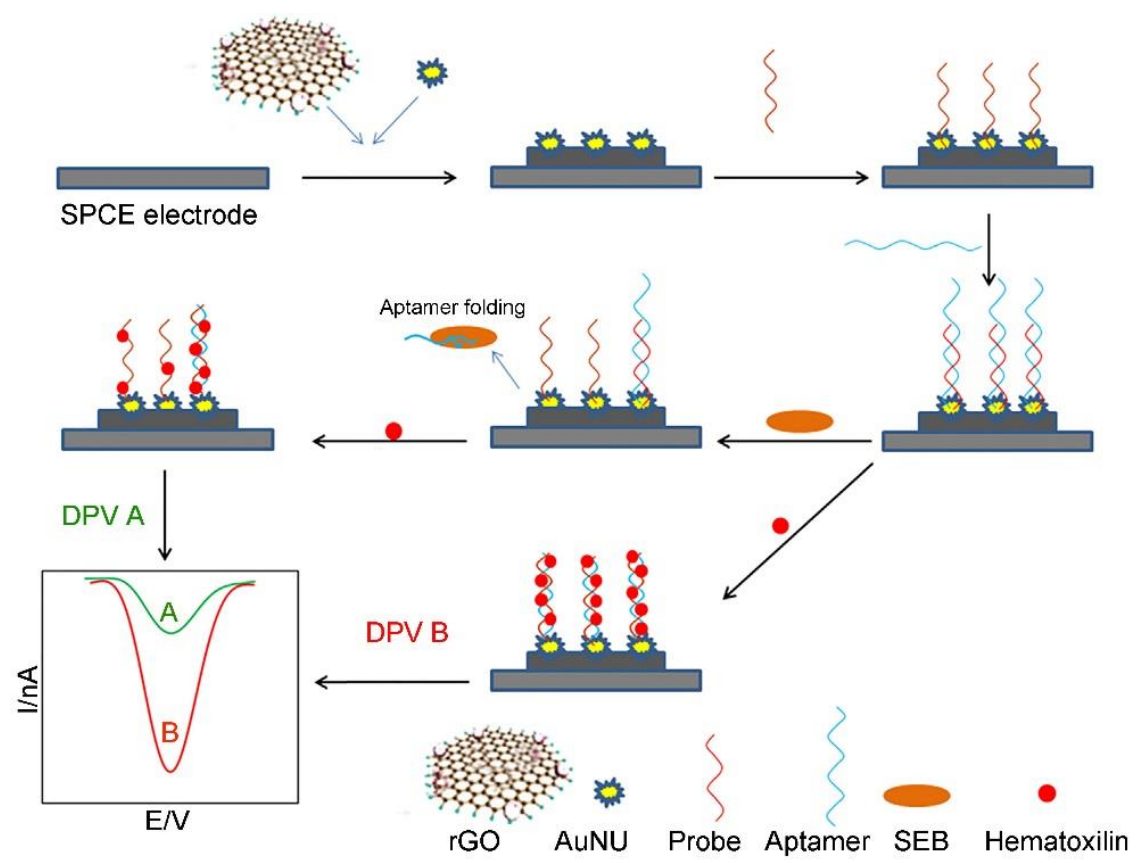

Figure 3. Schematic representation of the fabrication process of the SEB aptasensor by using rGO and AuNU-modified screen printed carbon electrodes (SPCEs) (adapted from Nodoushan et al. 2019 [91], Copyright 2018 Elsevier B.V. and reproduced with permission).

\section{Detection of Fungal Toxins}

\subsection{Aflatoxins}

Aflatoxins are a widespread group of food toxins that are produced by Aspergillus flavus and Aspergillus parasiticus [92-95]. There are four main types of aflatoxins: $B_{1}, B_{2}, G_{1}$, and $G_{2}$, which are based on their fluorescence characteristics under UV light (blue or green) excitation and relative chromatographic mobility in thin-layer chromatography. Among the aflatoxins, AFB1 is considered the most toxic aflatoxin, and can cause cancers, such as hepatocellular carcinoma. Various 2D nanomaterial-based electrochemical biosensors have been constructed for detecting $\mathrm{AFB}_{1}$ in various matrixes [96-113]. Srivastava et al. have developed a series of functionalized GO nanocomposite-based electrochemical biosensors for profiling $\mathrm{AFB}_{1}$ in foods since they developed the first rGO-based $\mathrm{AFB}_{1}$ immunosensor through the covalent conjugation of the monoclonal anti-AFB1 antibodies onto an rGO modified indium tin oxide (ITO) electrode in 2013 [96-99]. Among these electrochemical biosensors, the functionalized GO/rGO-based nanocomposites are employed in different roles, such as catalysts, electroactive probes and immobilization platforms for improving the biosensing performance. For instance, benefiting from the highly crystalline properties of the rGO-Ni NPs sheets (Ni nanoparticle decorated rGO sheets) along with the excellent electro-catalytic properties, the rGO-Ni NPs-ITO-based $\mathrm{AFB}_{1}$ immunosensor exhibits high sensitivity $\left(129.6 \mathrm{~mA} \mathrm{ng}^{-1} \mathrm{~mL} \mathrm{~cm}^{-2}\right.$ ), long term stability (up to 6 weeks) and low LOD (0.16 $\left.\mathrm{ng} \mathrm{mL}^{-1}\right)$ [99]. Photoelectrochemical (PEC) biosensors have attracted great attention in the biological analytical field as the PEC method can obtain high sensitivity without expensive equipment. Recently, Hao et al. developed a dual channel self-reference PEC biosensor for detecting $\mathrm{AFB}_{1}$ through immobilization of the $\mathrm{AFB}_{1}$ aptamer onto cadmium telluride (CdTe) and the CdTe-GO modified ITO electrode (as shown in Figure 4) [104]. In this case, CdTe and CdTe-GO were used to generate an anodic photocurrent and cathodic photocurrent, respectively. The AFB1 aptamer was immobilized on the PEC active materials, CdTe and CdTe-GO, through a covalent reaction or physical absorption, respectively. In the presence of AFB1, the aptamer is released from the CdTe-GO surface, resulting in the recovery of the cathodic photocurrent, while the aptamer forms an aptamer-AFB1 complex on the CdTe surface, and the anodic photocurrent decreases further. Compared 
to traditional PEC biosensors, the CdTe/CdTe-GO-based dual channel self-reference PEC biosensor can provide better precision and reliability, which is promising for detection of $\mathrm{AFB}_{1}$ in complex matrixes. Very recently, Peng et al. developed an AFB1 electrochemical aptasensor based on tetrahedral DNA nanostructures (TDNs) immobilized on three dimensionally ordered macroporous $\mathrm{MoS}_{2}-\mathrm{AuNPs}_{\mathrm{N}}$ hybrids (3DOM MoS 2 -AuNPs) [107]. 3DOM MoS 2 -AuNPs can enhance the immobilization amount of TDNs and facilitate the movement of the electrons between the electrode surface and the redox probe. In combination with a HRP functionalized magnetic signal amplifier, the aptasensor achieves a good linear range (from $0.1 \mathrm{fg} \mathrm{mL}^{-1}$ to $0.1 \mu \mathrm{g} \mathrm{mL}^{-1}$ ) and a LOD of $0.01 \mathrm{fg} \mathrm{mL}^{-1}$, which can be employed to detect $\mathrm{AFB}_{1}$ in grain products such as rice and wheat powder samples.

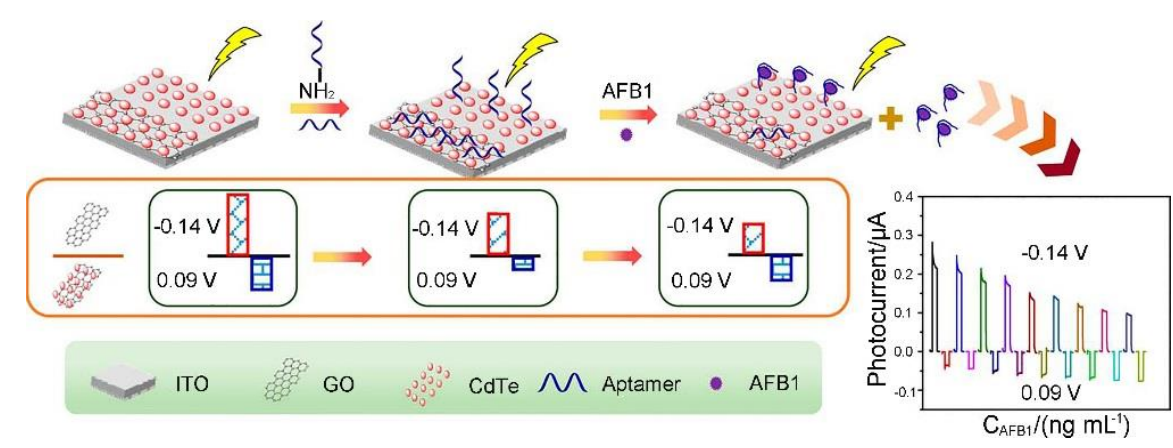

Figure 4. Schematic representation of the construction of the self-reference photoelectrochemical (PEC) biosensor for the detection of $\mathrm{AFB}_{1}$ (adapted from Hao et al. 2017 [104], Copyright 2017 American Chemical Society and reproduced with permission).

\subsection{Ochratoxin}

Ochratoxin A (OTA) is the major mycotoxin of the ochratoxin group, which are produced primarily by fungi (e.g., Aspergillus ochraceus, Penicillium verrucosum and Aspergillus niger) [114-117]. OTA has strong nephrotoxicity, and is the main etiological agent responsible for human Balkan endemic nephropathy (BEN) and associated urinary tract tumors. In addition, high concentrations of OTA has certain hepatotoxicity. During the last 5 years, several 2D nanomaterial-based electrochemical biosensors including immunosensors and aptasensors have also been developed for sensing OTA [118-131]. For instance, a series of aptasensors based on rGO-AuNP nanocomposites have been constructed by Wang's group [118-120]. The rGO-AuNP nanocomposites have well-dispersity and controllable surface coverage of AuNPs on the rGO sheet, which can be employed as an excellent signal amplified platform for an impedimetric aptasensor and/or an efficient nanocarrier for the CdTe QD (cadmium telluride quantum dot)-based amperometric aptasensor. As a typical example, a label free electrochemical aptasensor was successfully fabricated for ultrasensitive detection of OTA through using the CdTe QDs modified graphene/AuNPs nanocomposite (GAu/CdTe) as a signal amplifier. The as-proposed label-free amperometric aptasensor exhibits a wide linear range from $0.2 \mathrm{pg} \mathrm{mL}^{-1}$ to $4 \mathrm{ng} \mathrm{mL} \mathrm{mL}^{-1}$ and a low LOD $\left(0.07 \mathrm{pg} \mathrm{mL}^{-1}\right)$, which has great potential in various applications, such as food safety monitoring and clinical diagnosis [120]. Bulbul et al. developed a non-enzymatic nanocatalyst-based amperometric aptasensor for OTA detection through immobilization of the OTA aptamer on the GO-modified electrode and the electro-oxidation of a nanoceria (nCe) tag [121]. In this case, GO was used as an electrode material for facilitating the electron transport and enhancing the electrochemical response because it has high conductivity and peroxidase-like activity. In particular, the synergistic effect between the catalase activity of $\mathrm{nCe}$ and the peroxidase like activity of GO increases the OTA detection sensitivity significantly. The LOD of as-proposed amperometric aptasensor is calculated to be $0.1 \mathrm{nmol} \mathrm{L}^{-1}$, which is below the European Union regulatory limits of OTA (such as $5 \mu \mathrm{g} \mathrm{kg}{ }^{-1}$ in raw cereal grains, $3 \mu \mathrm{g} \mathrm{kg}^{-1}$ in products derived from cereals, and $2 \mu \mathrm{g} \mathrm{kg}^{-1}$ in grape juice). The analytical reliability of the amperometric aptasensor has been demonstrated by the detection of OTA in spiked corn samples. Recently, Wang et al. constructed a ratiometric electrochemical aptasensor 
for OTA detection through assembly of a methylene blue (MB)-modified OTA aptamer (MB-aptamer) on the $\mathrm{MoS}_{2}$ nanosheet/AuNP (MoS $\left.2-\mathrm{AuNP}\right)$ nanocomposite-decorated gold electrode through the host-guest recognition of $\beta$-cyclodextrin ( $\beta$-CD) (as shown in Figure 5) [128]. After interaction with OTA, the MB-aptamer was disassembled because of G-quadruplex formation, leading to a decrease in the peak current of MB. Whereas the free ferrocenecarboxylic acid was recognized by $\beta-C D$ and produced signals in the current, resulting in the "ratiometric" effect. With the combination of high electrocatalytic activity of $\mathrm{MoS}_{2}$-AuNP nanocomposites and the recognition capability of $\beta-\mathrm{CD}$, the as-proposed ratiometric electrochemical aptasensor possesses satisfactory superiority in terms of detection range (from $0.1 \mathrm{nmol} \mathrm{L}^{-1}$ to $50 \mathrm{nmol} \mathrm{L}^{-1}$ ), sensitivity (a LOD of $0.06 \mathrm{nmol} \mathrm{L}^{-1}$ ), and accuracy $(6.5 \%$ of the relative standard deviation (RSD)). The practicability of the aptasensor was successfully demonstrated by detecting OTA in red wine samples.

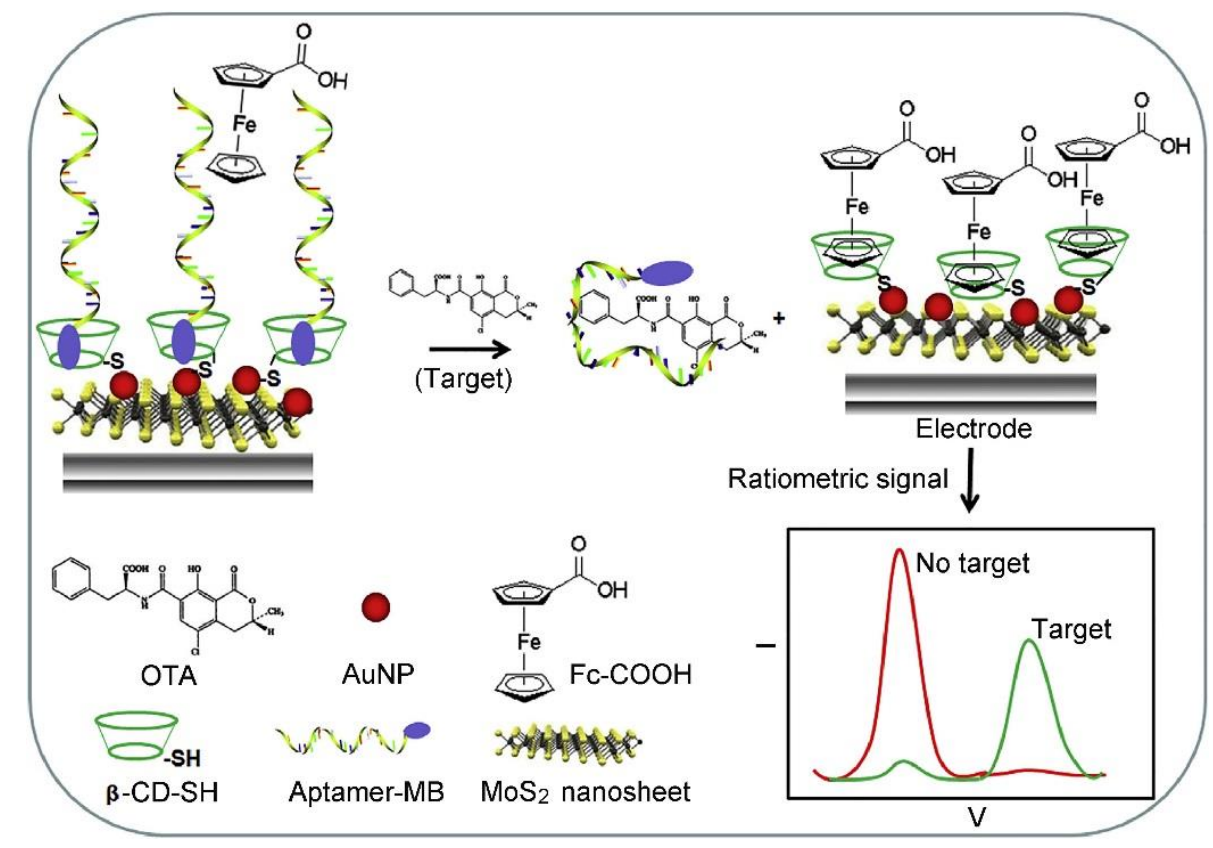

Figure 5. Schematic representation of the fabrication of the ratiometric electrochemical aptasensor for OTA detection based on nanocomposites of gold nanoparticle and $\mathrm{MoS}_{2}$ nanosheets with $\beta-\mathrm{CD}-\mathrm{SH}$ (thiolated $\beta$-CD) (adapted from Wang et al. 2018 [128], Copyright 2018 Elsevier Ltd. and reproduced with permission).

\subsection{Mycotoxins Produced by Fusarium}

The 2D nanomaterial-based electrochemical biosensors have also been developed for detecting other mycotoxins produced by Fusarium including deoxynivalenol (DON), fumonisin 1 (FB1), and zearalenone (ZEN) [132-137]. Shi et al. developed an aptasensor for sensitive FB1 detection by using the dual amplification of AuNPs and graphene/thionine nanocomposites (GSTH) [132]. GSTH served as electrochemical probes, which exhibit a strong electrochemical signal because the graphene has excellent conductivity and a large surface area for immobilizing a large amount of thionine molecules. The as-prepared aptasensor has a six orders of magnitude linear range with a LOD of $1 \mathrm{pg} \mathrm{mL}{ }^{-1}$. Lu et al. fabricated an electrochemical immunosensor based on a graphene nanocomposite for rapid and sensitive detection of two mycotoxins, DON and FB1 by using correspondent anti-toxin antibodies (as shown in Figure 6) [134]. In this case, the disposable SPCE was used as a sensing platform, which was modified by AuNPs and polypyrrole (PPy)-electrochemical rGO (PPy/ErGO) nanocomposite film. The film exhibits effective anti-toxin antibody immobilization capacity, enhanced electrical conductivity, and biocompatibility. The current signal of PPy/ErGO-SPCE is much better than that of PPy/rGO-SPCE. Benefiting from the excellent electrochemical response and effective antibody 
immobilization, the immunosensor exhibits good sensitivity, with a LOD of $4.2 \mathrm{ng} \mathrm{mL}{ }^{-1}$ for FB1 and $8.6 \mathrm{ng} \mathrm{mL} \mathrm{mL}^{-1}$ for DON. The immunosensor can be used for simultaneous detection of multiple co-contaminant mycotoxins individually in the practical samples (e.g., corn extracts) because it shows low matrix interference even in co-existing toxin environments. Very recently, Jiang et al. constructed a facile electrochemical immunosensor based on thin-layer $\mathrm{MoS}_{2}$ and thionin $\left(\mathrm{MoS}_{2}\right.$-Thi) composites for the sensitive and rapid detection of zearalenone (ZEA) in human biofluids (as shown in Figure 7) [136]. The as-prepared $\mathrm{MoS}_{2}$-Thi nanocomposites were employed as excellent electrochemical probes, as well as an efficient anti-ZEA antibody loading platform because $\mathrm{MoS}_{2}$ retains the electrochemical activity of Thi, and has a large surface area. The $\mathrm{MoS}_{2}$-Thi-based electrochemical immunosensor has good ZEA detection performance including a wide linear range $\left(0.01\right.$ to $\left.50 \mathrm{ng} \mathrm{mL}^{-1}\right)$, low LOD $\left(0.005 \mathrm{ng} \mathrm{mL}^{-1}\right.$ ZEA in both the plasma and urine), excellent selectivity, rapid responding time (20 min), acceptable stability (retained more than $85 \%$ detection capability at $4{ }^{\circ} \mathrm{C}$ for 10 days) and good practicability (detection of ZEA in real human biofluids).

(A)

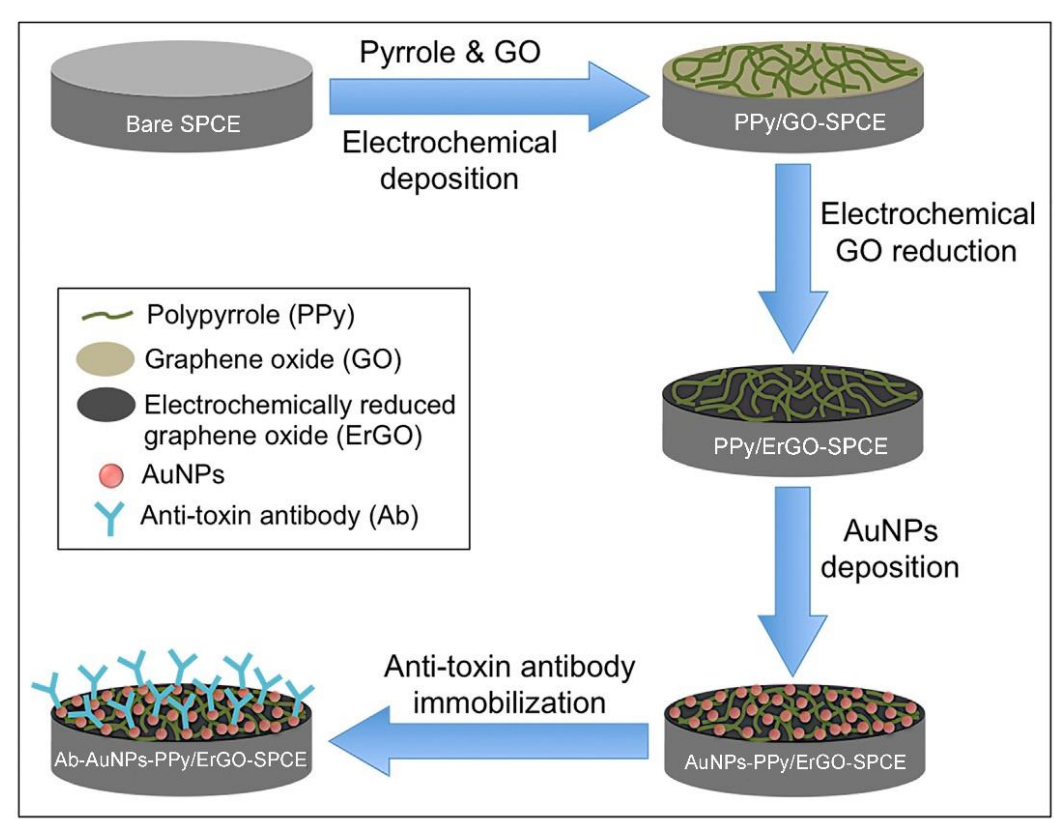

(B)

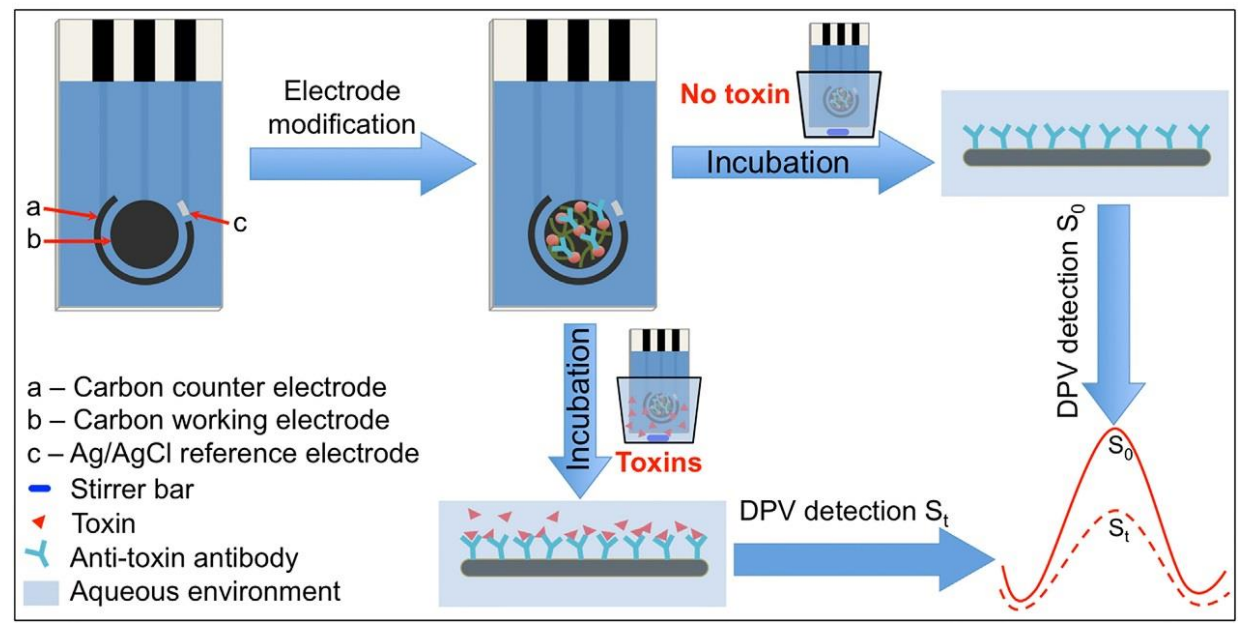

Figure 6. (A) Schematic representation of fabrication of the immunosensor and (B) detection of mycotoxins (adapted from Lu et al. 2016 [134], Copyright 2016 Elsevier Ltd. and reproduced with permission). 

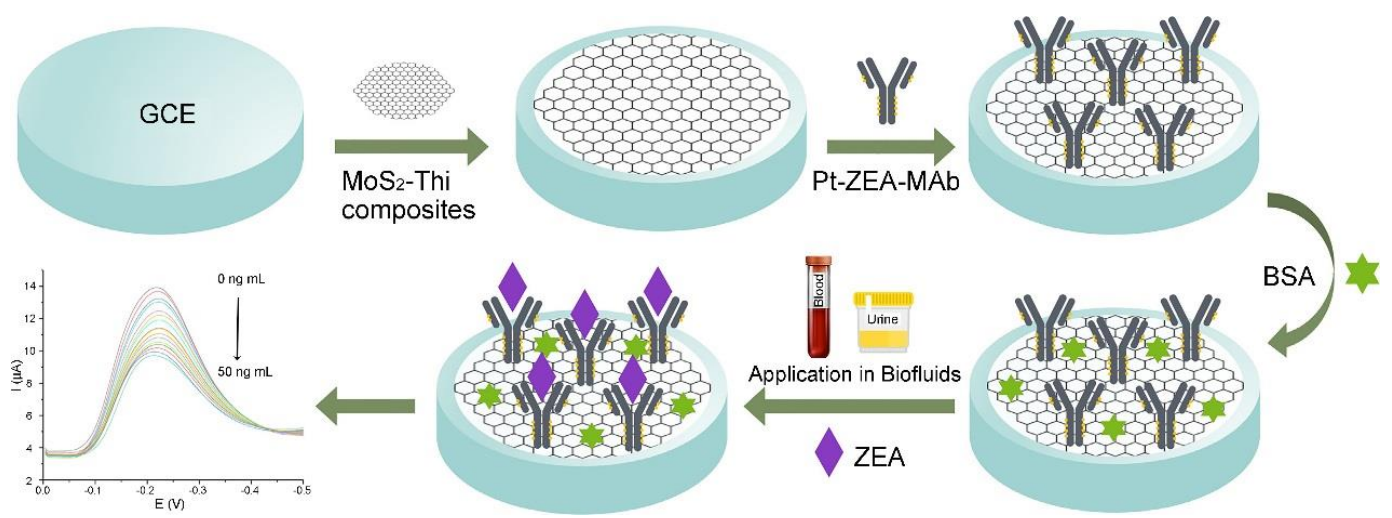

Figure 7. Schematic representation of the electrochemical immunosensor based on $\mathrm{MoS}_{2}$-Thi composites for the rapid detection of ZEA in biofluids (adapted from Jiang et al. 2019 [136], Copyright 2019 Elsevier B.V. and reproduced with permission).

\section{Detection of Algal Toxins}

\subsection{Microcystins}

Microcystins (MCs), a group of toxins produced by a number of cyanobacteria species, are monocyclic heptapeptides with the general structure cyclo(D)-Ala-X-(D)-erythro-b-methyliso-Asp-Y-Adda-(D)-iso-Glu-N-meth-yldehydro-Ala (X and Y represent L-amino acids). They are the most common cyano-toxins [138-142]. The unusual Adda amino acid, unique to MCs, is responsible for the toxicity of the molecule. There are more than 100 known variants of MCs, which are found in a wide variety of aquatic environments, in particular, eutrophic waters. Exposure to MCs via consumption of poisoned drinking-water or eating contaminated fish can cause permanent multiple organ injuries, developmental effects, reproductive effects and cancer. Therefore, it is important to develop highly sensitive methods for on-site monitoring of MCs. In addition, as the most potent congener, the Microcystin-LR (MC-LR) is commonly used to evaluate the toxicological data on the effects of MCs. The maximum tolerance limit of MC-LR concentration is $1 \mu \mathrm{g} \mathrm{L} \mathrm{L}^{-1}$ in different water sources by the WHO provisional guideline. Electrochemical biosensors, including 2D nanomaterial-based amperometric immunosensors, impedimetric aptasensors, and PEC aptasensors, have been extensively employed to detect MCs/MC-LR [143-159]. Li et al. have fabricated an electrochemical immunosensor based on GO-AuNP nanocomposites for MC-LR detection in water samples though layer-by-layer alternate electrodeposition of $\mathrm{GO}$ and chloroauric acid $\left(\mathrm{HAuCl}_{4}\right)$ on the GCE surface for 20 cycles [147]. The GO-AuNP-decorated GCE was then modified by the conducting polymer (poly(2,5-di-(2-thienyl)-1-pyrrole-1-(p-benzoicacid)) and 1-iso-butyl-3-methylimidazolium bis(tri-fluoromethane-sulfonyl) imide ionic liquid (IL). A polyclonal antibody of MC-LR was immobilized on the electrode by the conventional EDC/NHS reaction. The GO-AuNP nanocomposites enhance electron transfer of $\mathrm{Fe}(\mathrm{CN})_{6}{ }^{3-/ 4-}$ to the electrode while the IL acts as the stabilizer of the antibody. The as-developed electrochemical immunosensor has good repeatability (e.g., RSD $=1.2 \%$ ) and long-term stability (e.g., retain $95 \%$ activity over a 20 weeks storage period), and can detect MC-LR in water samples with a very low LOD of $3.7 \times 10^{-17} \mathrm{~mol} \mathrm{~L}^{-1}$. Recently, He et al. synthesized a kind of magnetic rGO nanocomposite $\left(\mathrm{Fe}_{3} \mathrm{O}_{4} @ \mathrm{PDA} / \mathrm{RGO}\right)$ for constructing a MC-LR electrochemical immunosensor by using the hydrothermal treatment of $\mathrm{Fe}_{3} \mathrm{O}_{4}$ nanocluster@Polydopamine core@shell nanoparticles $\left(\mathrm{Fe}_{3} \mathrm{O}_{4} @ \mathrm{PDA}\right.$ ) with GO (as shown in Figure 8) [153]. Due to its surface area and easy separation, the $\mathrm{Fe}_{3} \mathrm{O}_{4} @ \mathrm{PDA} / \mathrm{RGO}$ clearly enhances the antigen immobilization ability of the electrode. Then, a secondary-antibody and circularization DNA template were conjugated on gold nanorods (AuNRs) for recognizing the captured MC-LR-antibody pair on the $\mathrm{Fe}_{3} \mathrm{O}_{4} @ P D A / R G O-m o d i f i e d$ electrode surface and rolling circle amplification. Because the rolling circle amplification strategy can generate massive repeated DNA sequences, the signal of the immunosensor is greatly enhanced by 
hybridization of electrochemical active probes with the repeated DNA sequences. Under the optimal conditions, the as-developed immunosensor has good detection performance including a wide linear range (from $0.01 \mathrm{mg} \mathrm{L}^{-1}$ to $\left.50 \mathrm{mg} \mathrm{L}^{-1}\right)$ and a low LOD $\left(0.007 \mathrm{mg} \mathrm{L}^{-1}\right)$, which can be employed to detect MC-LR in real samples (e.g., river water). A series of PEC aptasensor-based various GO/rGO nanocomposites have been developed for sensitively detecting MC-LR since the PEC method has been considered to be a more sensitive technique, ascribed to the combination of electrochemical and optical techniques $[149,151,157]$. For instance, Du et al. developed a PEC aptasensing platform based on AgI-nitrogen-doped graphene (AgI-NG) nanocomposites as photo-cathodes and a MC-LR aptamer as the recognition unit [157]. The PEC aptasensor has a LOD of $3.7 \times 10^{-17} \mathrm{~mol} \mathrm{~L}{ }^{-1}$, which can be employed to determine MC-LR in inaquatic products (e.g., fish extracts). As a graphene analogue, the $\mathrm{MoS}_{2}$ nanosheet is also expected to serve as an excellent functional material for development of electrochemical biosensors. As shown in Figure 9, Pang et al. constructed an enzyme-free electrochemical immunosensor for detecting MC-LR based on a unique competitive detection scheme using $\mathrm{MoS}_{2}$ nanosheets/BSA-stabilized gold nanocluster $\left(\mathrm{MoS}_{2} / \mathrm{AuNC}\right.$ ) nanocomposites and $\mathrm{Au}$ core/Pt shell nanoparticles (Au@PtNPs) [155]. Due to its large surface area and excellent biocompatibility, the $\mathrm{MoS}_{2} / \mathrm{AuNC}$ nanocomposite was employed as a platform for improving the biological activity and immobilizing amount of antibody on the electrode surface. The as-developed enzyme-free electrochemical immunosensor has good stability (e.g., 92\% of the initial level remained after being stored at $4{ }^{\circ} \mathrm{C}$ for four weeks), and exhibits a wide linear range of $1.0 \mathrm{ng} \mathrm{L}-1-1.0 \mathrm{mg} \mathrm{L}^{-1}$ with a LOD of $0.3 \mathrm{ng} \mathrm{L}^{-1}$. The practicability of the as-developed immunosensor has been demonstrated by detection of MC-LR in various water samples including tap water, lake water, and river water. The MC-LR amounts in these water samples detected by the immunosensor are consistent with those determined by the conventional ELISA method. Very recently, Liu et al. developed an electrochemical aptasensor for sensitive and selective determination of microcystin-LR by using a dual signal amplification system consisting of a ternary nanocomposite and HRP [159]. The ternary nanocomposites were prepared by depositing AuNPs on the $\mathrm{MoS}_{2}$ nanosheets covered with $\mathrm{TiO}_{2}$ nanobeads (TiONBs). The MoS nanosheet-modified TiONBs provide a large surface area for efficiently immobilizing AuNPs and thiolated MC-LR aptamers. Due to the combination of good electron transfer and high catalytic capability of the ternary composite, the aptasensor has a wide dynamic range from 0.005 to $30 \mathrm{nmol} \mathrm{L}^{-1}$ and a LOD of $0.002 \mathrm{nmol} \mathrm{L}^{-1}$.

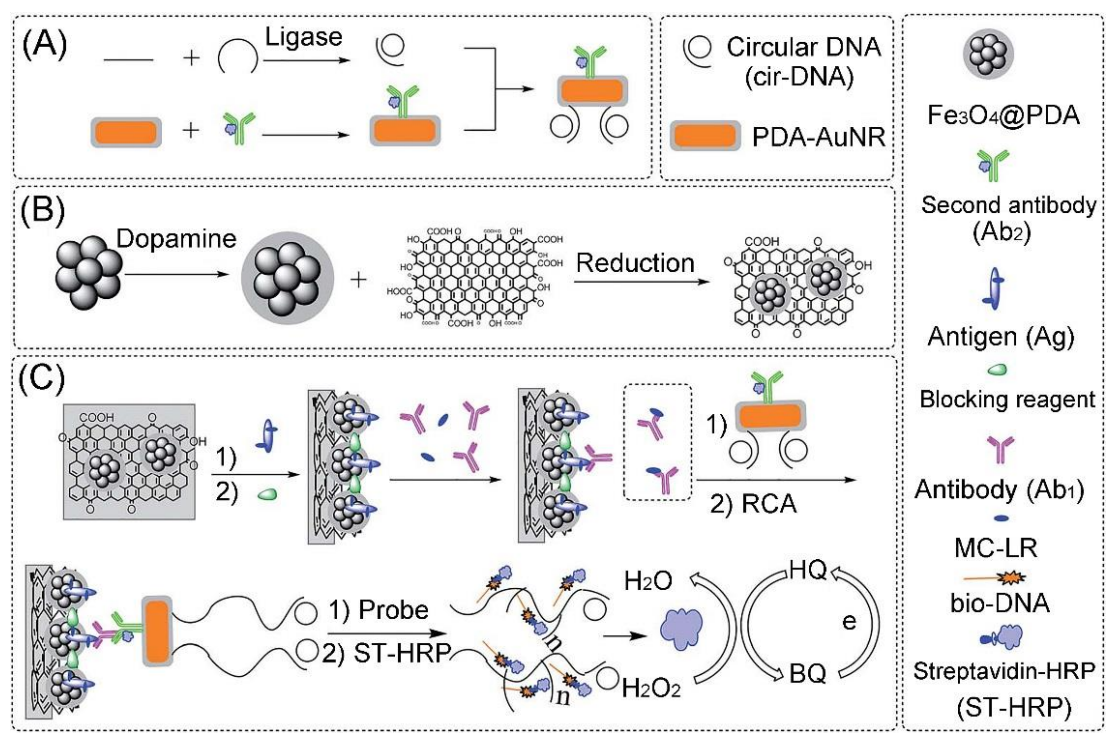

Figure 8. Schematic representation of (A) the preparation of $\mathrm{Ab}_{2}-\mathrm{AuNR}$-cirDNA, (B) the formation of magnetic graphene composite, and $(\mathbf{C})$ the construction process of the proposed MC-LR immunosensor (adapted from He et al. 2017 [153], Copyright 2017 The Royal Society of Chemistry and reproduced with permission). 


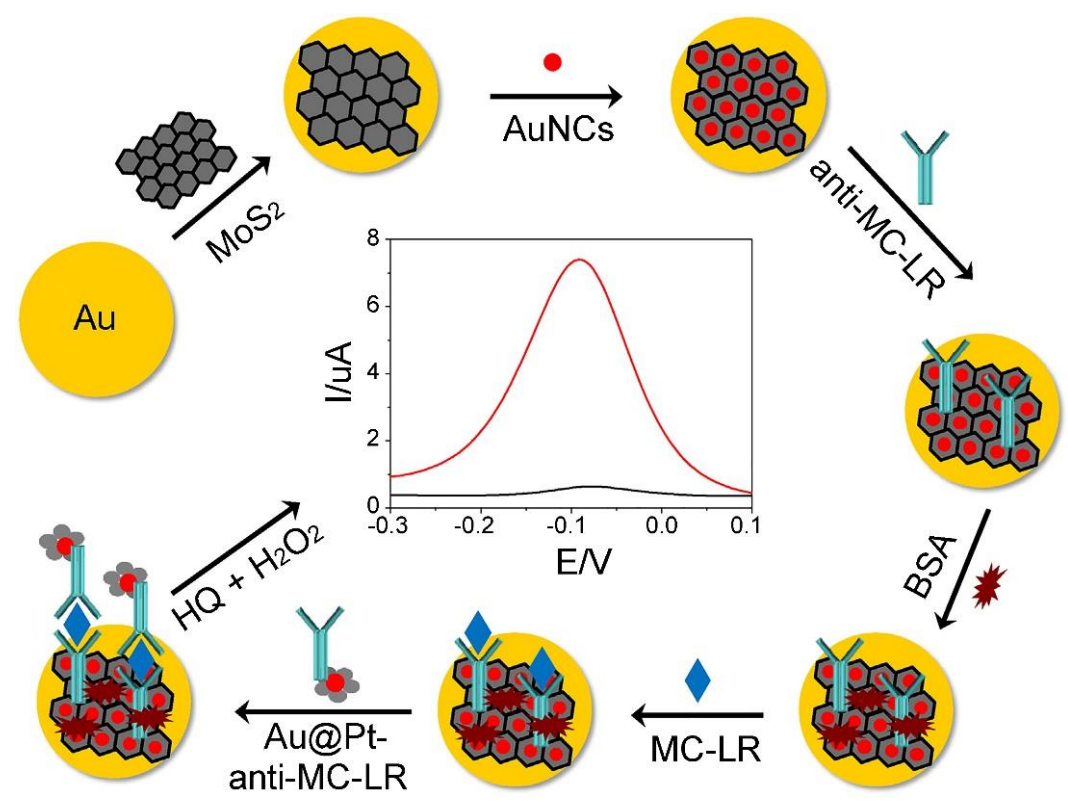

Figure 9. Schematic representation of the preparation and detection principle of the MC-LR immunosensor (adapted from Pang et al. 2018 [155], Copyright 2018 Elsevier B.V. and reproduced with permission).

\subsection{Cylindrospermopsin}

Cylindrospermopsin (CYN), a tricyclic alkaloid with a molecular mass of $415 \mathrm{Da}$, is a common cyanotoxin, and is produced by cyanobacteria including Cylindrospermopsis, Anabaena, Umezakia, and Aphanizomenon [160-166]. Cylindrospermopsin can cause DNA/RNA strand breakage and promote hepatotoxicity, cytoxicity, and genotoxicity through inhibiting protein translation and binding to DNA. The Falconer recommends a tentative guideline value of $1 \mathrm{ug} \mathrm{L}^{-1}$ for cylindrospermopsin [166]. Recently, we fabricated a label-free impedimetric aptasensor based on a GO-thionine (TH-GO) nanocomposite for detection of $\mathrm{CYN}$ by covalent binding of the amino-terminated aptamer of CYN to TH-GO nanocomposite-modified GCE via glutaraldehyde (as shown in Figure 10) [167]. Using $\left[\mathrm{Fe}(\mathrm{CN})_{6}\right]^{4-/ 3-}$ as an electrochemically active probe, $\mathrm{CYN}$ can be detected as low as $0.117 \mathrm{ng} \mathrm{mL}^{-1}$ in water. The as-proposed aptasensor has been employed for detecting CYN in spiked lake water samples, and satisfactory recoveries were obtained. With its superior performance characteristics combined with long-term stability (it retained approximately $74.7 \%$ of its initial value after being stored at $4{ }^{\circ} \mathrm{C}$ for 30 days) and excellent reusability ( $\mathrm{RSD}=2.1 \%$ within 10 reacting cycles), the as-developed aptasensor is a potential candidate for on-site CYN analysis.
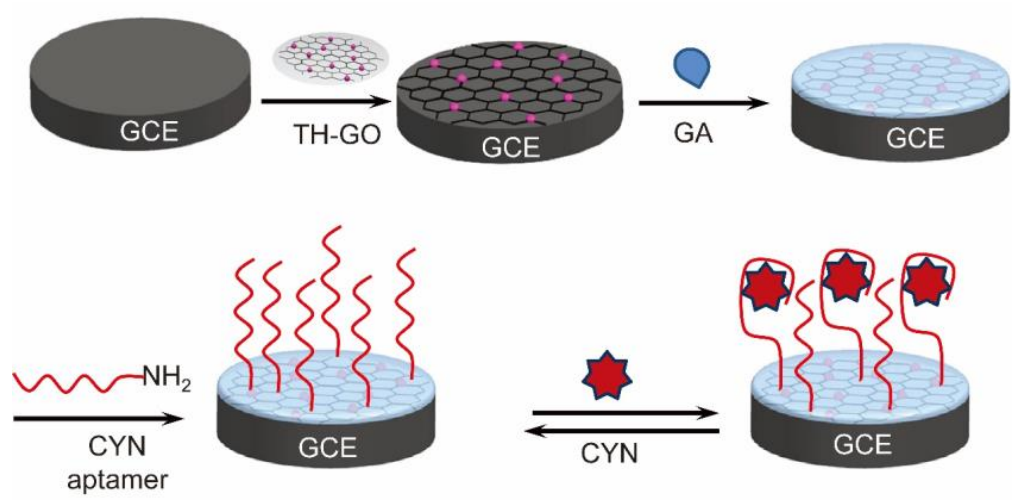

Figure 10. Schematic representation of the label-free impedimetric aptasensor for detecting cylindrospermopsin (adapted from Zhao et al. 2015 [167], Copyright 2015 The Royal Society of Chemistry and reproduced with permission). 


\subsection{Saxitoxins}

As a group of carbamate alkaloid neurotoxins, saxitoxins (STXs) contain sixteen variants, which are commonly associated with "red tides," and found as a paralytic shellfish toxin. Australia has a drinking water guideline of $3 \mu \mathrm{g} \mathrm{L}{ }^{-1}$ of STX equivalence. Recently, Bratakou et al. constructed a miniaturized potentiometric STX immunosensor on graphene nanosheets with incorporated lipid films and anti-STX (the natural STX receptor) [168]. The potentiometric STX immunosensor can be easily miniaturized because graphene nanosheets have a high surface area and good conductivity, and incorporate well with the lipid bilayer membrane for immobilizing anti-STX antibody. The potentiometric STX immunosensor exhibits several advantages such as a rapid response time (ca. 5-20 min), low LOD (1 nmol L $\left.{ }^{-1}\right)$ with high sensitivity (ca. $60 \mathrm{mV} /$ decade of toxin concentration), good reproducibility (maximum deviation only $6.8 \%$ ), reusability, high selectivity and long shelf life (>1 month). The practicability of the method was demonstrated by detecting STX in lake water and shellfish samples. This graphene nanosheets with incorporated lipid films could be used to develop biosensors for monitoring other toxins.

\subsection{Brevetoxin B}

Brevetoxins (BTXs) are potent cyclic polyether neurotoxins, which are naturally produced by the marine "red tide" dinoflagellate, Karenia brevis. BTX exposure can cause neurological shellfish poisoning (NSP), which has increased in geographical distribution over the past decade [139]. As early as 2012, Tang et al. constructed a magneto-controlled electrochemical immunosensor for sensitive detection of brevetoxin B (BTX-2) in seafood by using guanine-assembled graphene nanoribbons (GGNRs) as molecular tags on a home-made magnetic carbon paste electrode [169]. In this case, the GGNRs were modified by bioconjugates of BSA with BTX-2 (BTX-2-BSA), while monoclonal mouse anti-BTX-2 antibodies were covalently immobilized on the surface of magnetic beads for the capture of BTX-2 through a competitive-type immunoassay format. The formed magnetic immunocomplex was integrated on the electrode with an external magnet, followed by determination in $\mathrm{pH} 6.5$ phosphate-buffered solution containing $2 \mu \mathrm{mol} \mathrm{L}{ }^{-1} \mathrm{Ru}(\mathrm{bpy})_{3} \mathrm{Cl}_{2}$. Compared with pure guanine-labeled molecular tags, the GNR-labeled electrochemical immunoassays show a much wider linear range and lower detection limit. Under optimal conditions, the electrochemical signals decreased by increasing concentration of BTX-2 in the sample. The magneto-controlled immunosensing platform has a wide dynamic range from $1.0 \mathrm{pg} \mathrm{mL}^{-1}$ to $10 \mathrm{ng} \mathrm{mL}^{-1}$ with a LOD of $1.0 \mathrm{pg} \mathrm{mL}^{-1} \mathrm{BTX}-2$. The analytical reliability of the magneto-controlled electrochemical immunosensing platform is demonstrated by the detection of BTX-2 in 12 spiked samples including S. constricta, M. senhousia and T. granosa. The as-obtained results are consistent with those of traditional ELISA.

\subsection{Okadaic Acid}

The family of okadaic acid (OA) biotoxins consists of OA and its analogues dinophysistoxins 1, 2 and 3 (named as DTX-1, DTX-2 and DTX-3) [170]. As a by-product of harmful algal blooms (HABs), OA originates from the algal genera Prorocentrum and Dynophysis. Eissa and Zourob developed a direct competitive voltammetric immunosensor for the sensitive detection of OA based on carboxyphenyl-functionalized graphene-modified SPCEs (GSPCEs) [171]. The anti-OA antibodies were immobilized on the GSPE via carbodiimide chemistry, where OA and OA-ovalbumin (OA-OVA) in solution compete for their binding to the immobilized antibody. Benefitting from the unique electrochemical properties of graphene and the stability of the carboxyphenyl layer, the immunosensor

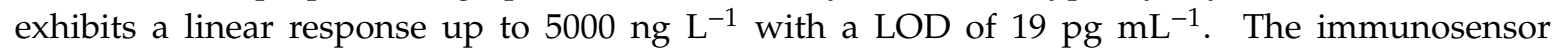
was successfully applied for detecting OA in the spiked shellfish extracts, showing good recovery. Very recently, Ramalingam et al. fabricated an electrochemical microfluidic biochip for detecting OA by using phosphorene-gold (BP-Au) nanocomposite-modified SPCE (as shown in Figure 11) [172]. The as-synthesized BP-Au nanocomposite not only serves as a backbone to the aptamer sequence, but also significantly enhances the electrochemical response of the aptasensor. DPV measurements 
revealed a LOD of 8 pmol L ${ }^{-1}$, while a linear range was found between $10 \mathrm{nmol} \mathrm{L}{ }^{-1}$ to $250 \mathrm{nmol} \mathrm{L}^{-1}$. The electrochemical aptasensor has excellent selectivity and can be employed to detect OA in fresh mussel extracts. The results suggest that the microfluidic electrochemical aptasensor can be served as an easy-to-use POC device for an on-field assay.

(A)

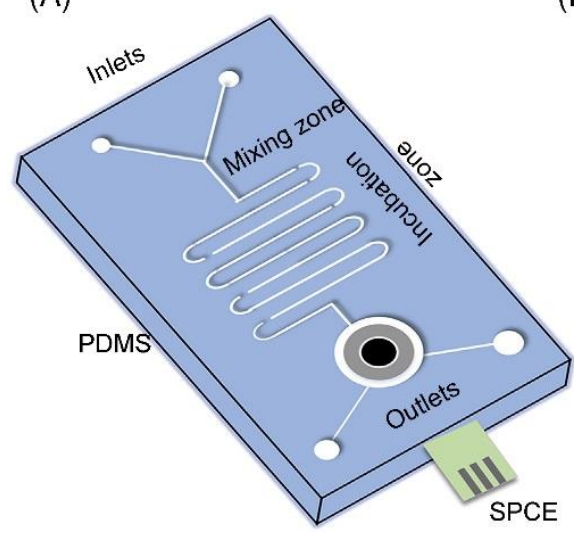

(B)

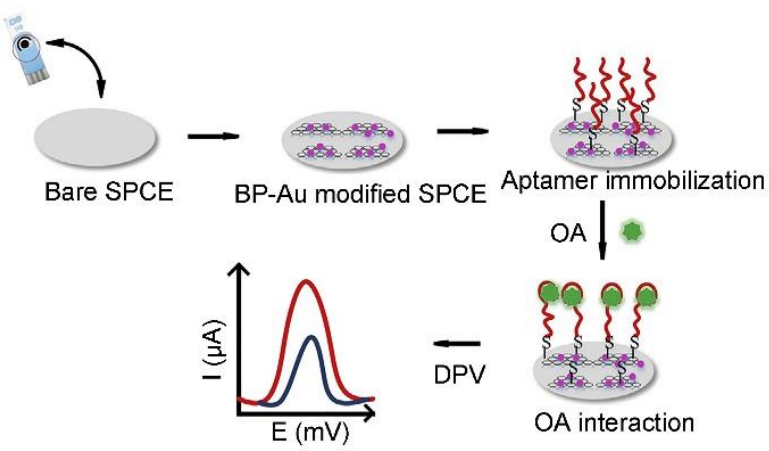

Figure 11. A microfluidic electrochemical aptasensor for the detection of okadaic acid: (A) graphic of the fabricated PDMS microfluidic chip, and (B) schematic representation of the process of aptamer-based sensing (adapted from Ramalingam et al. 2019 [172], Copyright 2019 Elsevier B.V. and reproduced with permission).

\section{Conclusions and Perspective}

This review has summarized the recent progress in electrochemical biosensing systems for the determination of various microbial toxins by using 2D nanomaterials and their nanocomposites (hereinafter referred to 2D nanomaterials). The literature results demonstrate that the integration of 2D nanomaterials into electrochemical biosensors has led to the significant enhancement of their analytical efficiency, including a high sensitivity (e.g., very low LODs) with a wide linearity range over several orders of magnitude, rapid assaying time, and simplified analytical procedures, and they are also suitable for on-site monitoring. During the determination processes, 2D nanomaterials mainly have two roles: as substrates for efficient immobilization of capturing biomolecules (e.g., anti-toxin antibodies and aptamers) and high active electrochemical probes for signal amplification. Some 2D nanomaterials have multifunctionality, and are capable of playing both of the above roles. Furthermore, the 2D nanomaterial-based electrochemical aptasensors have been proven as reusable platforms for detecting toxins.

Although the 2D nanomaterial-based electrochemical biosensors show great promise within laboratory investigations, such as the detection of toxins in buffer solutions and/or toxin-spiked samples, the technique remains relatively immature in development compared with standard toxin assaying tools (e.g., HPLC and ELISA), and several technical challenges are still awaiting further investigation. (1) The multiple electrode modification steps are normally required for increasing the recognition performance of the immobilized aptamer or antibody, and reducing background signals. This phenomenon requires manual and tedious work, which not only increases the preparation cost of biosensors, but also leads to poor reproducibility of the results among laboratories. In order to simplify the biosensor construction procedure, future research should increase the reaction efficiency of 2D nanomaterials with biomolecules (such as an antibody and apatmer) and decrease unreacted activity groups on the surface of 2D nanomaterials after biomolecule immobilization. Furthermore, development of automatic methods for modification of 2D nanomaterials on the electrode surface may help to increase the inter-laboratory reproducibility of biosensors. (2) The properties of 2D nanomaterials, including their electrical conductivity, PEC conversion capability and biomolecule immobilization capacity, are strongly dependent on their morphology, such as shape, size, purity, and defects. Therefore, 2D-nanomaterials 
should be fully characterized before biosensor fabrication. In further research, researchers are strongly encouraged to establish the synthesis standard of 2D-nanomaterials in order to improve the reproducibility of 2D nanomaterial-based electrochemical biosensors. In addition, the as-proposed synthesis strategy should be easily employed to produce 2D-nanomaterials on a large-scale by simply adjusting the synthesis conditions, such as increasing the amount of reactants. This factor is very important for industrialization of the 2D nanomaterial-based electrochemical sensors. (3) To date, one kind of 2D nanomaterial-based electrochemical biosensor is merely confined to determine a single microbial toxin. Because of coexistence of various microbial toxins in nature, future research should focus on development of a universal biosensor production technology for enabling rapid analysis of various toxins. (4) In order to achieve large-scale application, in particular for on-site monitoring, further efforts should be directed toward the development of 2D nanomaterial-based electrochemical biosensors, which can be used to detect toxins in practical samples such as various agricultural, food stuff, body fluids, and environmental sectors (e.g., lake water and sea water). The practicability of 2D nanomaterial-based electrochemical biosensors could be improved through integration of the biosensor with other techniques such as microfluidic devices and microarrays because miniaturization will help to increase the detection throughput, e.g., recognize multiple elements simultaneously. (5) Currently, aptamers and antibodies are mainly used for recognition of the toxins. In order to obtain high selectivity, the key epitope residues of the aptamer and antibody should be unrestrained after immobilization on the 2D nanomaterials. In addition, the molecular structures of the aptamer and antibody are sensitive to the environmental conditions (such as temperature, ionic strength and interferences from sample matrices). The high apparent affinity of the aptamer and/or antibody could be achieved through immobilization of the aptamer and/or antibody by stereoselective reactions (e.g., chick chemistry, DNA hybridization, biotin-avidin recognition). In addition, future research should aim to increase the biocompatibility of 2D nanomaterials. Finally, we expect commercialization of 2D nanomaterial-based electrochemical biosensors into practical procedures for detecting multiple toxins in practical samples through efforts of researchers in different disciplines, which would give significant benefit to the public.

Author Contributions: Conceptualization, Z.L. and X.L. contributed equally for preparation of the draft of this article, M.J. prepared the figures, G.S.G. and Z.W. contributed equally to its further elaboration and discussion. All authors have read and agreed to the published version of the manuscript.

Funding: This research was funded by the National Natural Science Foundation of China (Grant no. 21775145) to Z.W.

Conflicts of Interest: The authors declare no conflict of interest.

\section{References}

1. Shao, Y.; Wang, J.; Wu, H.; Liu, J.; Aksay, I.A.; Lin, Y. Graphene based electrochemical sensors and biosensors: A review. Electroanalysis 2010, 22, 1027-1036. [CrossRef]

2. Brownson, D.A.C.; Banks, C.E. Graphene electrochemistry: An overview of potential applications. Analyst 2010, 135, 2768-2778. [CrossRef] [PubMed]

3. Yang, W.; Ratinac, K.R.; Ringer, S.P.; Thordarson, P.; Gooding, J.J.; Braet, F. Carbon nanomaterials in biosensors: Should you use nanotubes or graphene? Angew. Chem. Int. Ed. 2010, 49, 2114-2138. [CrossRef] [PubMed]

4. Kuila, T.; Bose, S.; Khanra, P.; Mishra, A.K.; Kim, N.H.; Lee, J.H. Recent advances in graphene-based biosensors. Biosens. Bioelectron. 2011, 26, 4637-4648. [CrossRef] [PubMed]

5. Liu, Y.; Dong, X.; Chen, P. Biological and chemical sensors based on graphene materials. Chem. Soc. Rev. 2012, 41, 2283-2307. [CrossRef] [PubMed]

6. Yang, T.; Yang, R.; Chen, H.; Nan, F.; Ge, T.; Jiao, K. Electrocatalytic activity of molybdenum disulfide nanosheets enhanced by self-doped polyaniline for highly sensitive and synergistic determination of adenine and guanine. ACS Appl. Mater. Interfaces 2015, 7, 2867-2872. [CrossRef]

7. Kannan, P.K.; Late, D.J.; Morgan, H.; Rout, C.S. Recent developments in 2D layered inorganic nanomaterials for sensing. Nanoscale 2015, 7, 13293-13312. [CrossRef] 
8. Reverte, L.; Prieto-Simon, B.; Campas, M. New advances in electrochemical biosensors for the detection of toxins: Nanomaterials, magnetic beads and microfluidics systems. A review. Anal. Chim. Acta 2016, 908, 8-21. [CrossRef]

9. Kukkar, M.; Tuteja, S.K.; Sharma, A.L.; Kumar, V.; Paul, A.K.; Kim, K.H.; Sabherwal, P.; Deep, A. A new electrolytic synthesis method for few-layered $\mathrm{MoS}_{2}$ nanosheets and their robust biointerfacing with reduced antibodies. ACS Appl. Mater. Interfaces 2016, 8, 16555-16563. [CrossRef]

10. Lim, S.A.; Ahmed, M.U. Electrochemical immunosensors and their recent nanomaterial-based signal amplification strategies: A review. RSC Adv. 2016, 6, 24995-25014. [CrossRef]

11. Hu, Y.; Huang, Y.; Tan, C.; Xiao, Z.; Lu, Q. Two-dimensional transition metal dichalcogenide nanomaterials for biosensing applications. Mater. Chem. Front. 2016, 1, 24-36. [CrossRef]

12. Justino, C.I.L.; Comes, A.R.; Freitas, A.C.; Duarte, A.C.; Rocha-Santos, T.A.P. Graphene based sensors and biosensors. TrAC Trends Anal. Chem. 2017, 91, 53-66. [CrossRef]

13. Wang, Y.H.; Huang, K.J.; Wu, X. Recent advances in transition-metal dichalcogenides based electrochemical biosensors: A review. Biosens. Bioelectron. 2017, 97, 305-316. [CrossRef] [PubMed]

14. Gan, X.; Zhao, H.; Quan, X. Two-dimensional $\mathrm{MoS}_{2}$ : A promising building block for biosensors. Biosens. Bioelectron. 2017, 89, 56-71. [CrossRef] [PubMed]

15. Goud, K.Y.; Kalisa, S.K.; Kumar, V.; Tsang, Y.F.; Lee, S.E.; Gobi, K.V.; Kim, K.H. Progress on nanostructured electrochemical sensors and their recognition elements for detection of mycotoxins: A review. Biosens. Bioelectron. 2018, 121, 205-222. [CrossRef] [PubMed]

16. Jiang, C.; Lan, L.; Yao, Y.; Zhao, F.; Ping, J. Recent progress in application of nanomaterial-enabled biosensors for ochratoxin A detection. TrAC Trends Anal. Chem. 2018, 102, 236-249. [CrossRef]

17. Lv, M.; Liu, Y.; Geng, J.; Kou, X.; Xin, Z.; Yang, D. Engineering nanomaterials-based biosensors for food safety detection. Biosens. Bioelectron. 2018, 106, 122-128. [CrossRef]

18. Jin, W.; Maduraiveeran, G. Nanomaterial-based environmental sensing platforms using state-of-the-art electroanalytical strategies. J. Anal. Sci. Technol. 2018, 9, 18. [CrossRef]

19. Chen, Q.; Zhu, L.; Chen, J.; Jiang, T.; Ye, H.; Ji, H.; Tsang, S.; Zhao, Z.; Yi, T.; Chen, H. Recent progress in nanomaterial-based assay for the detection of phytotoxins in foods. Food Chem. 2019, 277, 162-178. [CrossRef]

20. Krishnan, S.K.; Singh, E.; Singh, P.; Meyyappan, M.; Nalwa, H.S. A review on graphene-based nanocomposites for electrochemical and fluorescent biosensors. RSC Adv. 2019, 9, 8778-8881. [CrossRef]

21. Dalila, N.R.; Arshad, M.K.M.; Gopinath, S.C.B.; Norhaimi, W.M.W.; Fathil, M.F.M. Current and future envision on developing biosensors aided by 2D molybdenum disulfide $\left(\mathrm{MoS}_{2}\right)$ productions. Biosens. Bioelectron. 2019, 132, 248-264. [CrossRef] [PubMed]

22. Novoselov, K.S.; Geim, A.K.; Morozov, S.V.; Jiang, D.; Zhang, Y.; Dubonos, S.V.; Grigorieva, I.V.; Firsov, A.A. Electric field effect in atomically thin carbon films. Science 2004, 306, 666-669. [CrossRef] [PubMed]

23. Lee, C.; Wei, X.; Kysar, J.W.; Hone, J. Measurement of the elastic properties and intrinsic strength of monolayer graphene. Science 2008, 321, 385-388. [CrossRef] [PubMed]

24. Stoller, M.D.; Park, S.; Zhu, Y.; An, J.; Ruoff, R.S. Graphene-based ultracapacitors. Nano Lett. 2008, 8, 3498-3502. [CrossRef] [PubMed]

25. Ghosh, S.; Calizo, I.; Teweldebrhan, D.; Pokatilov, E.P.; Nika, D.L.; Balandin, A.A.; Bao, W.; Miao, F.; Lau, C.N. Extremely high thermal conductivity of graphene: Prospects for thermal management applications in nanoelectronic circuits. Appl. Phys. Lett. 2008, 92, 151911. [CrossRef]

26. Geim, A.K. Graphene: Status and prospects. Science 2009, 324, 1530-1534. [CrossRef] [PubMed]

27. Ponomarenko, L.A.; Yang, R.; Mohiuddin, T.M.; Katsnelson, M.I.; Novoselov, K.S.; Morozov, S.V.; Zhukov, A.A.; Schedin, F.; Hill, E.W.; Geim, A.K. Effect of a high-kappa environment on charge carrier mobility in graphene. Phys. Rev. Lett. 2009, 102, 206603. [CrossRef]

28. Ping, J.; Wu, J.; Wang, Y.; Ying, Y. Simultaneous determination of ascorbic acid, dopamine and uric acid using high-performance screen-printed graphene electrode. Biosens. Bioelectron. 2012, 34, 70-76. [CrossRef]

29. Campuzano, S.; Pedrero, M.; Nikoleli, G.P.; Pingarron, J.M.; Nikolelis, D.P. Hybrid 2D-nanomaterials-based electrochemical immunosensing strategies for clinical biomarkers determination. Biosens. Bioelectron. 2017, 89, 269-279. [CrossRef]

30. Stankovich, S.; Dikin, D.A.; Dommett, G.H.B.; Kohlhaas, K.M.; Zimney, E.J.; Stach, E.A.; Piner, R.D.; Nguyen, S.T.; Ruoff, R.S. Graphene-based composite materials. Nature 2006, 442, 282-286. [CrossRef]

31. Geim, A.K.; Novoselov, K.S. The rise of graphene. Nat. Mater. 2007, 6, 183-191. [CrossRef] 
32. Li, X.; Cai, W.; An, J.; Kim, S.; Nah, J.; Yang, D.; Piner, R.; Velamakanni, A.; Jung, I.; Tutuc, E.; et al. Large-area synthesis of high-quality and uniform graphene films on copper foils. Science 2009, 324, 1312-1314. [CrossRef] [PubMed]

33. Reina, A.; Jia, X.; Ho, J.; Nezich, D.; Son, H.; Bulovic, V.; Dresselhaus, M.S.; Kong, J. Large area, few-layer graphene films on arbitrary substrates by chemical vapor deposition. Nano Lett. 2009, 9, 30-35. [CrossRef] [PubMed]

34. Chhowalla, M.; Shin, H.S.; Eda, G.; Li, L.J.; Loh, K.P.; Zhang, H. The chemistry of two-dimensional layered transition metal dichalcogenide nanosheets. Nat. Chem. 2013, 5, 263-275. [CrossRef] [PubMed]

35. Georgakilas, V.; Otyepka, M.; Bourlinos, A.B.; Chandra, V.; Kim, N.; Kemp, K.C.; Hobza, P.; Zboril, R.; Kim, K.S. Functionalization of graphene: Covalent and non-covalent approaches, derivatives and applications. Chem. Rev. 2012, 112, 6156-6214. [CrossRef] [PubMed]

36. Kelly, K.F.; Billups, E. Synthesis of soluble graphite and graphene. Acc. Chem. Res. 2013, 46, 4-13. [CrossRef]

37. Xu, M.; Liang, T.; Shi, M.; Chen, H. Graphene-like two-dimensional materials. Chem. Rev. 2013, 113, 3766-3798. [CrossRef]

38. Ciesielski, A.; Samori, P. Graphene via sonication assisted liquid-phase exfoliation. Chem. Soc. Rev. 2014, 43, 381-398. [CrossRef]

39. Randviir, E.P.; Brownson, D.A.C.; Banks, C.E. A decade of graphene research: Production, applications and outlook. Mater. Today 2014, 17, 426-432. [CrossRef]

40. Duong, D.L.; Yun, S.J.; Lee, Y.H. van der Waals layered materials: Opportunities and challenges. ACS Nano 2017, 11, 11803-11830. [CrossRef]

41. Manzeli, S.; Ovchinnikov, D.; Pasquier, D.; Yazyev, O.V.; Kis, A. 2D transition metal dichalcogenides. Nat. Rev. Mater. 2017, 2, 17033. [CrossRef]

42. Yu, X.; Cheng, H.; Zhang, M.; Zhao, Y.; Qu, L.; Shi, G. Graphene-based smart materials. Nat. Rev. Mater. 2017, 2, 0014. [CrossRef]

43. Li, H.; Li, Y.; Aljarb, A.; Shi, Y.; Li, L.J. Epitaxial growth of two-dimensional layered transition-metal dichalcogenides: Growth mechanism, controllability, and scalability. Chem. Rev. 2018, 118, 6134-6150. [CrossRef] [PubMed]

44. Ambrosi, A.; Chua, C.K.; Bonanni, A.; Pumera, M. Electrochemistry of graphene and related materials. Chem. Rev. 2014, 114, 7150-7188. [CrossRef]

45. Wang, L.; Xiong, Q.; Xiao, F.; Duan, H. 2D nanomaterials based electrochemical biosensors for cancer diagnosis. Biosens. Bioelectron. 2017, 89, 136-151. [CrossRef]

46. Chimene, D.; Alge, D.L.; Gaharwar, A.K. Two-dimensional nanomaterials for biomedical applications: Emerging trends and future prospects. Adv. Mater. 2015, 27, 7261-7284. [CrossRef]

47. Lawn, J.E.; Cousens, S.; Zupan, J. 4 million neonatal deaths: When? where? why? Lancet 2005, 365, 891-900. [CrossRef]

48. Fowler, C.C.; Chang, S.J.; Gao, X.; Geiger, T.; Stack, G.; Galan, J.E. Emerging insights into the biology of typhoid toxin. Curr. Opin. Microbiol. 2017, 35, 70-77. [CrossRef]

49. Blanco, J. Accumulation of dinophysis toxins in bivalve molluscs. Toxins 2018, 10, 453. [CrossRef]

50. Pitois, F.; Fastner, J.; Pagotto, C.; Dechesne, M. Multi-toxin occurrences in ten french water resource reservoirs. Toxins 2018, 10, 283. [CrossRef]

51. Janik, E.; Ceremuga, M.; Saluk-Bijak, J.; Bijak, M. Biological toxins as the potential tools for bioterrorism. Int. J. Mol. Sci. 2019, 20, 1181. [CrossRef]

52. Marchese, S.; Polo, A.; Ariano, A.; Velotto, S.; Costantini, S.; Severino, L. Aflatoxin B1 and M1: Biological properties and their involvement in cancer development. Toxins 2018, 10, 214. [CrossRef]

53. Partida-Martinez, L.P.; Hertweck, C. Pathogenic fungus harbours endosymbiotic bacteria for toxin production. Nature 2005, 437, 884-888. [CrossRef]

54. Koropatnick, T.A.; Engle, J.T.; Apicella, M.A.; Stabb, E.V.; Goldman, W.E.; McFall-Ngai, M.J. Microbial factor-mediated development in a host-bacterial mutualism. Science 2004, 306, 1186-1188. [CrossRef]

55. Richardson, S.D. Water analysis: Emerging contaminants and current issues. Anal. Chem. 2007, 79, 4295-4323. [CrossRef]

56. Berthiller, F.; Schuhmacher, R.; Adam, G.; Krska, R. Formation, determination and significance of masked and other conjugated mycotoxins. Anal. Bioanal. Chem. 2009, 395, 1243-1252. [CrossRef] 
57. Garcia-Galan, M.J.; Diaz-Cruz, M.S.; Barcelo, D. Combining chemical analysis and ecotoxicity to determine environmental exposure and to assess risk from sulfonamides. TrAC Trends Anal. Chem. 2009, 28, 804-819. [CrossRef]

58. Man, Y.; Liang, G.; Li, A.; Pan, L. Analytical methods for the determination of alternaria mycotoxins. Chromatographia 2017, 80, 9-22. [CrossRef]

59. Steil, D.; Pohlentz, G.; Legros, N.; Mormann, M.; Mellmann, A.; Karch, H.; Muething, J. Combining mass spectrometry, surface acoustic wave interaction analysis, and cell viability assays for characterization of shiga toxin subtypes of pathogenic Escherichia coil bacteria. Anal. Chem. 2018, 90, 8989-8997. [CrossRef]

60. Patel, P.D. (Bio)sensors for measurement of analytes implicated in food safety: A review. TrAC Trends Anal. Chem. 2002, 21, 96-115. [CrossRef]

61. Van Dorst, B.; Mehta, J.; Bekaert, K.; Rouah-Martin, E.; De Coen, W.; Dubruel, P.; Blust, R.; Robbens, J. Recent advances in recognition elements of food and environmental biosensors: A review. Biosens. Bioelectron. 2010, 26, 1178-1194. [CrossRef] [PubMed]

62. McGrath, T.F.; Elliott, C.T.; Fodey, T.L. Biosensors for the analysis of microbiological and chemical contaminants in food. Anal. Bioanal. Chem. 2012, 403, 75-92. [CrossRef] [PubMed]

63. Zhang, Z.; Yu, L.; Xu, L.; Hu, X.; Li, P.; Zhang, Q.; Ding, X.; Feng, X. Biotoxin sensing in food and environment via microchip. Electrophoresis 2014, 35, 1547-1559. [CrossRef] [PubMed]

64. Duracova, M.; Klimentova, J.; Fucikova, A.; Dresler, J. Proteomic methods of detection and quantification of protein toxins. Toxins 2018, 10, 99. [CrossRef]

65. Peltomaa, R.; Benito-Pena, E.; Moreno-Bondi, M.C. Bioinspired recognition elements for mycotoxin sensors. Anal. Bioanal. Chem. 2018, 410, 747-771. [CrossRef]

66. Mustafa, F.; Andreescu, S. Chemical and biological sensors for food-quality monitoring and smart packaging. Foods 2018, 7, 168. [CrossRef]

67. Farabullini, F.; Lucarelli, F.; Palchetti, I.; Marrazza, G.; Mascini, M. Disposable electrochemical genosensor for the simultaneous analysis of different bacterial food contaminants. Biosens. Bioelectron. 2007, 22, 1544-1549. [CrossRef]

68. Bonel, L.; Vidal, J.C.; Duato, P.; Castillo, J.R. An electrochemical competitive biosensor for ochratoxin A based on a DNA biotinylated aptamer. Biosens. Bioelectron. 2011, 26, 3254-3259. [CrossRef]

69. Ye, Y.; Guo, H.; Sun, X. Recent progress on cell-based biosensors for analysis of food safety and quality control. Biosens. Bioelectron. 2019, 126, 389-404. [CrossRef]

70. Collins, M.D.; East, A.K. Phylogeny and taxonomy of the food-borne pathogen Clostridium botulinum and its neurotoxins. J. Appl. Microbiol. 1998, 84, 5-17. [CrossRef]

71. Bigalke, H.; Rummel, A. Medical aspects of toxin weapons. Toxicology 2005, 214, 210-220. [CrossRef] [PubMed]

72. Rummel, A.; Haefner, K.; Mahrhold, S.; Darashchonak, N.; Holt, M.; Jahn, R.; Beermann, S.; Karnath, T.; Bigalke, H.; Binz, T. Botulinum neurotoxins C, E and F bind gangliosides via a conserved binding site prior to stimulation-dependent uptake with botulinum neurotoxin F utilising the three isoforms of SV2 as second receptor. J. Neurochem. 2009, 110, 1942-1954. [CrossRef] [PubMed]

73. Eivazzadeh-Keihan, R.; Pashazadeh-Panahi, P.; Baradaran, B.; de la Guardia, M.; Hejazi, M.; Sohrabi, H.; Mokhtarzadeh, A.; Maleki, A. Recent progress in optical and electrochemical biosensors for sensing of Clostridium botulinum neurotoxin. TrAC Trends Anal. Chem. 2018, 103, 184-197. [CrossRef]

74. Narayanan, J.; Sharma, M.K.; Ponmariappan, S.; Sarita; Shaik, M.; Upadhyay, S. Electrochemical immunosensor for botulinum neurotoxin type-E using covalently ordered graphene nanosheets modified electrodes and gold nanoparticles-enzyme conjugate. Biosens. Bioelectron. 2015, 69, 249-256. [CrossRef] [PubMed]

75. Chan, C.Y.; Guo, J.; Sun, C.; Tsang, M.K.; Tian, F.; Hao, J.; Chen, S.; Yang, M. A reduced graphene oxide-Au based electrochemical biosensor for ultrasensitive detection of enzymatic activity of botulinum neurotoxin A. Sens. Actuators B 2015, 220, 131-137. [CrossRef]

76. Afkhami, A.; Hashemi, P.; Bagheri, H.; Salimian, J.; Ahmadi, A.; Madrakian, T. Impedimetic immunosensor for the label-free and direct detection of botulinum neurotoxin serotype A using $\mathrm{Au}$ nanoparticles/graphene-chitosan composite. Biosens. Bioelectron. 2017, 93, 124-131. [CrossRef]

77. Banno, Y.; Kobayashi, T.; Watanabe, K.; Ueno, K.; Nozawa, Y. 2 Toxins (D-1 and D-2) of Clostridium-Difficile causing antibiotic-associated colitis-purification and some characterization. Biochem. Int. 1981, 2, 629-635. 
78. Depitre, C.; Delmee, M.; Avesani, V.; L’Haridon, R.; Roels, A.; Popoff, M.; Corthier, G. Serogroup F strains of Clostridium difficile produce toxin B but not toxin A. J. Med. Microbiol. 1993, 38, 434-441. [CrossRef]

79. Sambol, S.P.; Merrigan, M.M.; Lyerly, D.; Gerding, D.N.; Johnson, S. Toxin gene analysis of a variant strain of Clostridium difficile that causes human clinical disease. Infect. Immun. 2000, 68, 5480-5487. [CrossRef]

80. Poutanen, S.M.; Simor, A.E. Clostridium difficile-associated diarrhea in adults. Can. Med. Assoc. J. 2004, 171, 51-58. [CrossRef]

81. Kuehne, S.A.; Cartman, S.T.; Heap, J.T.; Kelly, M.L.; Cockayne, A.; Minton, N.P. The role of toxin A and toxin B in Clostridium difficile infection. Nature 2010, 467, 711-713. [CrossRef] [PubMed]

82. Tenover, F.C.; Novak, W.S.; Woods, C.W.; Peterson, L.R.; Davis, T.; Schreckenberger, P.; Fang, F.C.; Dascal, A.; Gerding, D.N.; Nomura, J.H.; et al. Impact of strain type on detection of toxigenic clostridium difficile: Comparison of molecular diagnostic and enzyme immunoassay approaches. J. Clin. Microbiol. 2010, 48, 3719-3724. [CrossRef] [PubMed]

83. Joshi, L.T.; Mali, B.L.; Geddes, C.D.; Baillie, L. Extraction and sensitive detection of toxins A and B from the human pathogen Clostridium difficile in $40 \mathrm{~s}$ using microwave-accelerated metal-enhanced fluorescence. PLoS ONE 2014, 9, e104334. [CrossRef] [PubMed]

84. Fang, Y.S.; Chen, S.Y.; Huang, X.J.; Wang, L.S.; Wang, H.Y.; Wang, J.F. Simple approach for ultrasensitive electrochemical immunoassay of Clostridium difficile toxin B detection. Biosens. Bioelectron. 2014, 53, $238-244$. [CrossRef] [PubMed]

85. Liu, M.; Chang, D.; Li, Y. Discovery and biosensing applications of diverse RNA-cleaving DNAzymes. Acc. Chem. Res. 2017, 50, 2273-2283. [CrossRef] [PubMed]

86. Marrack, P.; Kappler, J. The staphylococcal enterotoxins and their relatives. Science 1990, 248, 705-711. [CrossRef]

87. Carfora, V.; Caprioli, A.; Marri, N.; Sagrafoli, D.; Boselli, C.; Giacinti, G.; Giangolini, G.; Sorbara, L.; Dottarelli, S.; Battisti, A.; et al. Enterotoxin genes, enterotoxin production, and methicillin resistance in Staphylococcus aureus isolated from milk and dairy products in Central Italy. Int. Dairy J. 2015, 42, $12-15$. [CrossRef]

88. Sharma, A.; Rao, V.K.; Kamboj, D.V.; Gaur, R.; Shaik, M.; Shrivastava, A.R. Enzyme free detection of staphylococcal enterotoxin B (SEB) using ferrocene carboxylic acid labeled monoclonal antibodies: An electrochemical approach. New J. Chem. 2016, 40, 8334-8341. [CrossRef]

89. Rapini, R.; Marrazza, G. Electrochemical aptasensors for contaminants detection in food and environment: Recent advances. Bioelectrochemistry 2017, 118, 47-61. [CrossRef]

90. Farka, Z.; Jurik, T.; Kovar, D.; Trnkova, L.; Skladal, P. Nanoparticle-based immunochemical biosensors and assays: Recent advances and challenges. Chem. Rev. 2017, 117, 9973-10042. [CrossRef]

91. Nodoushan, S.M.; Nasirizadeh, N.; Amani, J.; Halabian, R.; Fooladi, A.A.I. An electrochemical aptasensor for staphylococcal enterotoxin B detection based on reduced graphene oxide and gold nano-urchins. Biosens. Bioelectron. 2019, 127, 221-228. [CrossRef] [PubMed]

92. Gourama, H.; Bullerman, L.B. Aspergillus flavus and Aspergillus parasiticus: Aflatoxigenic fungi of concern in foods and feeds: A review. J. Food Prot. 1995, 58, 1395-1404. [CrossRef] [PubMed]

93. Bennett, J.W.; Klich, M. Mycotoxins. Clin. Microbiol. Rev. 2003, 16, 497-516. [CrossRef] [PubMed]

94. Keller, N.P.; Turner, G.; Bennett, J.W. Fungal secondary metabolism-From biochemistry to genomics. Nat. Rev. Microbiol. 2005, 3, 937-947. [CrossRef]

95. Geiser, D.M.; Pitt, J.I.; Taylor, J.W. Cryptic speciation and recombination in the aflatoxin-producing fungus Aspergillus flavus. Proc. Natl. Acad. Sci. USA 1998, 95, 388-393. [CrossRef]

96. Srivastava, S.; Kumar, V.; Ali, M.A.; Solanki, P.R.; Srivastava, A.; Sumana, G.; Saxena, P.S.; Joshi, A.G.; Malhotra, B.D. Electrophoretically deposited reduced graphene oxide platform for food toxin detection. Nanoscale 2013, 5, 3043-3051. [CrossRef]

97. Srivastava, S.; Ali, M.A.; Umrao, S.; Parashar, U.K.; Srivastava, A.; Sumana, G.; Malhotra, B.D.; Pandey, S.S.; Hayase, S. Graphene oxide-based biosensor for food toxin detection. Appl. Biochem. Biotechnol. 2014, 174, 960-970. [CrossRef]

98. Srivastava, S.; Abraham, S.; Singh, C.; Ali, M.A.; Srivastava, A.; Sumana, G.; Malhotra, B.D. Protein conjugated carboxylated gold@reduced graphene oxide for aflatoxin B-1 detection. RSC Adv. 2014, 5, 5406-5414. [CrossRef] 
99. Srivastava, S.; Kumar, V.; Arora, K.; Singh, C.; Ali, M.A.; Puri, N.K.; Malhotra, B.D. Antibody conjugated metal nanoparticle decorated graphene sheets for a mycotoxin sensor. RSC Adv. 2016, 6, 56518-56526. [CrossRef]

100. Zhou, L.; Li, R.; Li, Z.; Xia, Q.; Fang, Y.; Liu, J. An immunosensor for ultrasensitive detection of aflatoxin B-1 with an enhanced electrochemical performance based on graphene/conducting polymer/gold nanoparticles/the ionic liquid composite film on modified gold electrode with electrodeposition. Sens. Actuators B 2012, 174, 359-365.

101. Shu, J.; Qiu, Z.; Wei, Q.; Zhuang, J.; Tang, D. Cobalt-porphyrin-platinum-functionalized reduced graphene oxide hybrid nanostructures: A novel peroxidase mimetic system for improved electrochemical immunoassay. Sci. Rep. 2015, 5, 15113. [CrossRef] [PubMed]

102. Wang, D.; Hu, W.; Xiong, Y.; Xu, Y.; Li, C.M. Multifunctionalized reduced graphene oxide-doped polypyrrole/pyrrolepropylic acid nanocomposite impedimetric immunosensor to ultra-sensitively detect small molecular aflatoxin B-1. Biosens. Bioelectron. 2015, 63, 185-189. [CrossRef] [PubMed]

103. Basu, J.; Datta, S.; RoyChaudhuri, C. A graphene field effect capacitive Immunosensor for sub-femtomolar food toxin detection. Biosens. Bioelectron. 2015, 68, 544-549. [CrossRef] [PubMed]

104. Hao, N.; Zhang, Y.; Zhong, H.; Zhou, Z.; Hua, R.; Qian, J.; Liu, Q.; Li, H.; Wang, K. Design of a dual channel self-reference photoelectrochemical biosensor. Anal. Chem. 2017, 89, 10133-10136. [CrossRef] [PubMed]

105. Goud, K.Y.; Hayat, A.; Catanante, G.; Satyanarayana, M.; Gobi, K.V.; Marty, J.L. An electrochemical aptasensor based on functionalized graphene oxide assisted electrocatalytic signal amplification of methylene blue for aflatoxin B1 detection. Electrochim. Acta 2017, 244, 96-103. [CrossRef]

106. Mo, R.; He, L.; Yan, X.; Su, T.; Zhou, C.; Wang, Z.; Hong, P.; Sun, S.; Li, C. A novel aflatoxin B-1 biosensor based on a porous anodized alumina membrane modified with graphene oxide and an aflatoxin B-1 aptamer. Electrochem. Commun. 2018, 95, 9-13. [CrossRef]

107. Peng, G.; Li, X.; Cui, F.; Qiu, Q.; Chen, X.; Huang, H. Aflatoxin B1 electrochemical aptasensor based on tetrahedral DNA nanostructures functionalized three dimensionally ordered macroporous $\mathrm{MoS}_{2}$-AuNPs film. ACS Appl. Mater. Interfaces 2018, 10, 17551-17559. [CrossRef]

108. Geleta, G.S.; Zhao, Z.; Wang, Z. A novel reduced graphene oxide/molybdenum disulfide/polyaniline nanocomposite-based electrochemical aptasensor for detection of aflatoxin B-1. Analyst 2018, 143, 1644-1649. [CrossRef]

109. Bhardwaj, H.; Pandey, M.K.; Rajesh; Sumana, G. Electrochemical Aflatoxin B1 immunosensor based on the use of graphene quantum dots and gold nanoparticles. Microchim. Acta 2019, 186, 592. [CrossRef]

110. Beheshti-Marnani, A.; Hatefi-Mehrjardi, A.; Es'haghi, Z. A sensitive biosensing method for detecting of ultra-trace amounts of AFB1 based on "Aptamer/reduced graphene oxide" nano-bio interaction. Colloids Surf. B 2019, 175, 98-105. [CrossRef]

111. Tang, Y.; Liu, X.; Zheng, H.; Yang, L.; Li, L.; Zhang, S.; Zhou, Y.; Alwarappan, S. A photoelectrochemical aptasensor for aflatoxin B1 detection based on an energy transfer strategy between $\mathrm{Ce}-\mathrm{TiO}_{2} @ \mathrm{MoSe}_{2}$ and $\mathrm{Au}$ nanoparticles. Nanoscale 2019, 11, 9115-9124. [CrossRef] [PubMed]

112. Althagafi, I.I.; Ahmed, S.A.; El-Saidid, W.A. Fabrication of gold/graphene nanostructures modified ITO electrode as highly sensitive electrochemical detection of Aflatoxin B1. PLoS ONE 2019, 14, e0210652. [CrossRef] [PubMed]

113. Zhang, B.; Lu, Y.; Yang, C.; Guo, Q.; Nie, G. Simple "signal-on" photoelectrochemical aptasensor for ultrasensitive detecting AFB1 based on electrochemically reduced graphene oxide/poly(5-formylindole)/Au nanocomposites. Biosens. Bioelectron. 2019, 134, 42-48. [CrossRef] [PubMed]

114. O’Brien, E.; Dietrich, D.R. Ochratoxin A: The continuing enigma. Crit. Rev. Toxicol. 2005, 35, 33-60. [CrossRef] [PubMed]

115. Richard, J.L. Some major mycotoxins and their mycotoxicoses-An overview. Int. J. Food Microbiol. 2007, 119, 3-10. [CrossRef]

116. Pfohl-Leszkowicz, A.; Manderville, R.A. Ochratoxin A: An overview on toxicity and carcinogenicity in animals and humans. Mol. Nutr. Food Res. 2007, 51, 61-99. [CrossRef]

117. Pfohl-Leszkowicz, A.; Manderville, R.A. An update on direct genotoxicity as a molecular mechanism of ochratoxin A carcinogenicity. Chem. Res. Toxicol. 2012, 25, 252-262. [CrossRef] 
118. Jiang, L.; Qian, J.; Yang, X.; Yan, Y.; Liu, Q.; Wang, K.; Wang, K. Amplified impedimetric aptasensor based on gold nanoparticles covalently bound graphene sheet for the picomolar detection of ochratoxin A. Anal. Chim. Acta 2014, 806, 128-135. [CrossRef]

119. Qian, J.; Jiang, L.; Yang, X.; Yan, Y.; Mao, H.; Wang, K. Highly sensitive impedimetric aptasensor based on covalent binding of gold nanoparticles on reduced graphene oxide with good dispersity and high density. Analyst 2014, 139, 5587-5593. [CrossRef]

120. Hao, N.; Jiang, L.; Qian, J.; Wang, K. Ultrasensitive electrochemical Ochratoxin A aptasensor based on CdTe quantum dots functionalized graphene/Au nanocomposites and magnetic separation. J. Electroanal. Chem. 2016, 781, 332-338. [CrossRef]

121. Bulbul, G.; Hayat, A.; Andreescu, S. A generic amplification strategy for electrochemical aptasensors using a non-enzymatic nanoceria tag. Nanoscale 2015, 7, 13230-13238. [CrossRef] [PubMed]

122. Loo, A.H.; Bonanni, A.; Pumera, M. Mycotoxin aptasensing amplification by using inherently electroactive graphene-oxide nanoplatelet labels. Chemelectrochem 2015, 2, 743-747. [CrossRef]

123. Tang, J.; Huang, Y.; Zhang, C.; Liu, H.; Tang, D. Amplified impedimetric immunosensor based on instant catalyst for sensitive determination of ochratoxin A. Biosens. Bioelectron. 2016, 86, 386-392. [CrossRef] [PubMed]

124. Huang, K.J.; Shuai, H.L.; Chen, Y.X. Layered molybdenum selenide stacking flower-like nanostructure coupled with guanine-rich DNA sequence for ultrasensitive ochratoxin A aptasensor application. Sens. Actuators $B$ 2016, 225, 391-397. [CrossRef]

125. Sun, A.L.; Zhang, Y.F.; Sun, G.P.; Wang, X.N.; Tang, D. Homogeneous electrochemical detection of ochratoxin $\mathrm{A}$ in foodstuff using aptamer-graphene oxide nanosheets and DNase I-based target recycling reaction. Biosens. Bioelectron. 2017, 89, 659-665. [CrossRef]

126. Koh, V.; Ang, W.L.; Bonanni, A. The Role of Surface Chemistry in Impedimetric Aptasensing. Chemelectrochem 2018, 5, 3654-3659. [CrossRef]

127. Zhu, X.; Kou, F.; Xu, H.; Han, Y.; Yang, G.; Huang, X.; Chen, W.; Chi, Y.; Lin, Z. Label-free ochratoxin A electrochemical aptasensor based on target-induced noncovalent assembly of peroxidase-like graphitic carbon nitride nanosheet. Sens. Actuators B 2018, 270, 263-269. [CrossRef]

128. Wang, Y.; Ning, G.; Bi, H.; Wu, Y.; Liu, G.; Zhao, Y. A novel ratiometric electrochemical assay for ochratoxin A coupling Au nanoparticles decorated $\mathrm{MoS}_{2}$ nanosheets with aptamer. Electrochim. Acta 2018, 285, 120-127. [CrossRef]

129. Tang, J.; Xiong, P.; Cheng, Y.; Chen, Y.; Peng, S.; Zhu, Z.Q. Enzymatic oxydate-triggered AgNPs etching: A novel signal-on photoelectrochemical immunosensing platform based on Ag@AgCl nanocubes loaded RGO plasmonic heterostructure. Biosens. Bioelectron. 2019, 130, 125-131. [CrossRef]

130. Kaur, N.; Bharti, A.; Batra, S.; Rana, S.; Rana, S.; Bhalla, A.; Prabhakar, N. An electrochemical aptasensor based on graphene doped chitosan nanocomposites for determination of Ochratoxin A. Microchem. J. 2019, 144, 102-109. [CrossRef]

131. Sharifuzzaman, M.; Barman, S.C.; Zahed, M.A.; San, N.J.; Park, J.Y. Green synthesis of reduced graphene oxide decorated with few-layered $\mathrm{MoS}_{2}$-nanoroses and $\mathrm{Au} / \mathrm{Pd} / \mathrm{Ag}$ trimetallic nanoparticles for ultrasensitive label-free immunosensing platforms. J. Electrochem. Soc. 2019, 166, B249-B257. [CrossRef]

132. Shi, Z.Y.; Zheng, Y.T.; Zhang, H.B.; He, C.H.; Wu, W.D.; Zhang, H.B. DNA Electrochemical aptasensor for detecting fumonisins B1 based on graphene and thionine nanocomposite. Electroanalysis 2015, 27, 1097-1103. [CrossRef]

133. Chen, X.; Huang, Y.; Ma, X.; Jia, F.; Guo, X.; Wang, Z. Impedimetric aptamer-based determination of the mold toxin fumonisin B1. Microchim. Acta 2015, 182, 1709-1714. [CrossRef]

134. Lu, L.; Seenivasan, R.; Wang, Y.C.; Yu, J.H.; Gunasekaran, S. An electrochemical immunosensor for rapid and sensitive detection of mycotoxins fumonisin B1 and deoxynivalenol. Electrochim. Acta 2016, 213, 89-97. [CrossRef]

135. Feng, R.; Zhang, Y.; Ma, H.; Wu, D.; Fan, H.; Wang, H.; Li, H.; Du, B.; Wei, Q. Ultrasensitive non-enzymatic and non-mediator electrochemical biosensor using nitrogen-doped graphene sheets for signal amplification and nanoporous alloy as carrier. Electrochim. Acta 2013, 97, 105-111. [CrossRef]

136. Jiang, K.; Nie, D.; Huang, Q.; Fan, K.; Tang, Z.; Wu, Y.; Han, Z. Thin-layer $\mathrm{MoS}_{2}$ and thionin composite-based electrochemical sensing platform for rapid and sensitive detection of zearalenone in human biofluids. Biosens. Bioelectron. 2019, 130, 322-329. [CrossRef] 
137. He, B.; Yan, X. An amperometric zearalenone aptasensor based on signal amplification by using a composite prepared from porous platinum nanotubes, gold nanoparticles and thionine-labelled graphene oxide. Microchim. Acta 2019, 186, 383. [CrossRef]

138. Dawson, R.M. The toxicology of microcystins. Toxicon 1998, 36, 953-962. [CrossRef]

139. Landsberg, J.H. The effects of harmful algal blooms on aquatic organisms. Rev. Fish. Sci. 2002, 10, 113-390. [CrossRef]

140. Codd, G.A.; Morrison, L.F.; Metcalf, J.S. Cyanobacterial toxins: Risk management for health protection. Toxicol. Appl. Pharmacol. 2005, 203, 264-272. [CrossRef]

141. Chen, L.; Chen, J.; Zhang, X.; Xie, P. A review of reproductive toxicity of microcystins. J. Hazard. Mater. 2016, 301, 381-399. [CrossRef] [PubMed]

142. Preece, E.P.; Hardy, F.J.; Moore, B.C.; Bryan, M. A review of microcystin detections in estuarine and marine waters: Environmental implications and human health risk. Harmful Algae 2017, 61, 31-45. [CrossRef]

143. Zhang, W.; Dixon, M.B.; Saint, C.; Teng, K.S.; Furumai, H. Electrochemical biosensing of Algal toxins in water: The current state-of-the-art. ACS Sens. 2018, 3, 1233-1245. [CrossRef] [PubMed]

144. Vogiazi, V.; de la Cruz, A.; Mishra, S.; Shanov, V.; Heineman, W.R.; Dionysiou, D.D. A comprehensive review: Development of electrochemical biosensors for detection of cyanotoxins in freshwater. ACS Sens. 2019, 4, 1151-1173. [CrossRef] [PubMed]

145. Wei, Q.; Zhao, Y.; Du, B.; Wu, D.; Cai, Y.; Mao, K.; Li, H.; Xu, C. Nanoporous PtRu alloy enhanced nonenzymatic immunosensor for ultrasensitive detection of microcystin-LR. Adv. Funct. Mater. 2011, 21, 4193-4198. [CrossRef]

146. Zhao, H.; Tian, J.; Quan, X. A graphene and multienzyme functionalized carbon nanosphere-based electrochemical immunosensor for microcystin-LR detection. Colloids Surf. B 2013, 103, 38-44. [CrossRef]

147. Li, R.; Xia, Q.; Li, Z.; Sun, X.; Liu, J. Electrochemical immunosensor for ultrasensitive detection of microcystin-LR based on graphene-gold nanocomposite/functional conducting polymer/gold nanoparticle/ionic liquid composite film with electrodeposition. Biosens. Bioelectron. 2013, 44, 235-240.

148. Du, H.L.; Fu, X.W.; Wen, Y.P.; Qiu, Z.J.; Xiong, L.M.; Hong, N.Z.; Yang, Y.H. A label-free immunosensor for microcystins-LR based on graphene and gold Nanocage. Chin. J. Anal. Chem. 2014, 42, 659-665. [CrossRef]

149. Tian, J.; Zhao, H.; Quan, X.; Zhang, Y.; Yu, H.; Chen, S. Fabrication of graphene quantum dots/silicon nanowires nanohybrids for photoelectrochemical detection of microcystin-LR. Sens. Actuators B 2014, 196, 532-538. [CrossRef]

150. Eissa, S.; Ng, A.; Siaj, M.; Zourob, M. Label-free voltammetric aptasensor for the sensitive detection of microcystin-LR using graphene-modified electrodes. Anal. Chem. 2014, 86, 7551-7557. [CrossRef]

151. Du, X.; Jiang, D.; Dai, L.; Zhou, L.; Hao, N.; Qian, J.; Qiu, B.; Wang, K. Fabricating photoelectrochemical aptasensor for selectively monitoring microcystin-LR residues in fish based on visible light-responsive $\mathrm{BiOBr}$ nanoflakes/N-doped graphene photoelectrode. Biosens. Bioelectron. 2016, 81, 242-248. [CrossRef] [PubMed]

152. Zhang, W.; Han, C.; Jia, B.; Saint, C.; Nadagouda, M.; Falaras, P.; Sygellou, L.; Vogiazi, V.; Dionysiou, D.D. A 3D graphene-based biosensor as an early microcystin-LR screening tool in sources of drinking water supply. Electrochim. Acta 2017, 236, 319-327. [CrossRef]

153. He, Z.; Wei, J.; Gan, C.; Liu, W.; Liu, Y. A rolling circle amplification signal-enhanced immunosensor for ultrasensitive microcystin-LR detection based on a magnetic graphene-functionalized electrode. RSC Adv. 2017, 7, 39906-39913. [CrossRef]

154. Zhang, Y.; Chen, M.; Li, H.; Yan, F.; Pang, P.; Wang, H.; Wu, Z.; Yang, W. A molybdenum disulfide/gold nanorod composite-based electrochemical immunosensor for sensitive and quantitative detection of microcystin-LR in environmental samples. Sens. Actuators B 2017, 244, 606-615. [CrossRef]

155. Pang, P.; Teng, X.; Chen, M.; Zhang, Y.; Wang, H.; Yang, C.; Yang, W.; Barrow, C.J. Ultrasensitive enzyme-free electrochemical immunosensor for microcystin-LR using molybdenum disulfide/gold nanoclusters nanocomposites as platform and Au@Pt core-shell nanoparticles as signal enhancer. Sens. Actuators B 2018, 266, 400-407. [CrossRef]

156. Hu, Y.X.; Shang, F.; Liu, Y.; Wang, S.; Hu, Y.F.; Guo, Z.Y. A label-free electrochemical immunosensor based on multi-functionalized graphene oxide for ultrasensitive detection of microcystin-LR. Chem. Pap. 2017, 72, 71-79. [CrossRef] 
157. Du, X.; Jiang, D.; Li, H.; Hao, N.; You, T.; Wang, K. An intriguing signal-off responsive photoelectrochemical aptasensor for ultrasensitive detection of microcystin-LR and its mechanism study. Sens. Actuators B 2018, 259, 316-324. [CrossRef]

158. Zhang, W.; Jia, B.; Furumai, H. Fabrication of graphene film composite electrochemical biosensor as a pre-screening algal toxin detection tool in the event of water contamination. Sci. Rep. 2018, 8, 10686. [CrossRef]

159. Liu, X.; Tang, Y.; Liu, P.; Yang, L.; Li, L.; Zhang, Q.; Zhou, Y.; Khan, M.Z.H. A highly sensitive electrochemical aptasensor for detection of microcystin-LR based on a dual signal amplification strategy. Analyst 2019, 144, 1671-1678. [CrossRef]

160. Carmichael, W.W. Toxins of Cyanobacteria. Sci. Am. 1994, 270, 78-86. [CrossRef]

161. van Apeldoorn, M.E.; van Egmond, H.P.; Speijers, G.J.A.; Bakker, G.J.I. Toxins of cyanobacteria. Mol. Nutr. Food Res. 2007, 51, 7-60. [CrossRef] [PubMed]

162. Westrick, J.A.; Szlag, D.C.; Southwell, B.J.; Sinclair, J. A review of cyanobacteria and cyanotoxins removal/inactivation in drinking water treatment. Anal. Bioanal. Chem. 2010, 397, 1705-1714. [CrossRef] [PubMed]

163. Moreira, C.; Azevedo, J.; Antunes, A.; Vasconcelos, V. Cylindrospermopsin: Occurrence, methods of detection and toxicology. J. Appl. Microbiol. 2013, 114, 605-620. [CrossRef] [PubMed]

164. Quiblier, C.; Wood, S.; Echenique-Subiabre, I.; Heath, M.; Villeneuve, A.; Humbert, J.F. A review of current knowledge on toxic benthic freshwater cyanobacteria-Ecology, toxin production and risk management. Water Res. 2013, 47, 5464-5479.

165. Hinojosa, M.G.; Gutierrez-Praena, D.; Prieto, A.I.; Guzman-Guillen, R.; Jos, A.; Camean, A.M. Neurotoxicity induced by microcystins and cylindrospermopsin: A review. Sci. Total Environ. 2019, 668, 547-565. [CrossRef]

166. Falconer, I.R.; Humpage, A.R. Health risk assessment of cyanobacterial (blue-green algal) toxins in drinking water. Int. J. Environ. Res. Public Health 2005, 2, 43-50. [CrossRef]

167. Zhao, Z.; Chen, H.; Ma, L.; Liu, D.; Wang, Z. A label-free electrochemical impedance aptasensor for cylindrospermopsin detection based on thionine-graphene nanocomposites. Analyst 2015, 140, 5570-5577. [CrossRef]

168. Bratakou, S.; Nikoleli, G.P.; Siontorou, C.G.; Nikolelis, D.P.; Karapetis, S.; Tzamtzis, N. Development of an electrochemical biosensor for the rapid detection of saxitoxin based on air stable lipid films with incorporated anti-STX using graphene electrodes. Electroanalysis 2017, 29, 990-997. [CrossRef]

169. Tang, J.; Hou, L.; Tang, D.; Zhou, J.; Wang, Z.; Li, J.; Chen, G. Magneto-controlled electrochemical immunoassay of brevetoxin B in seafood based on guanine-functionalized graphene nanoribbons. Biosens. Bioelectron. 2012, 38, 86-93. [CrossRef]

170. Morabito, S.; Silvestro, S.; Faggio, C. How the marine biotoxins affect human health. Nat. Prod. Res. 2018, 32, 621-631. [CrossRef]

171. Eissa, S.; Zourob, M. A graphene-based electrochemical competitive immunosensor for the sensitive detection of okadaic acid in shellfish. Nanoscale 2012, 4, 7593-7599. [CrossRef] [PubMed]

172. Ramalingam, S.; Chand, R.; Singh, C.B.; Singh, A. Phosphorene-gold nanocomposite based microfluidic aptasensor for the detection of okadaic acid. Biosens. Bioelectron. 2019, 135, 14-21. [CrossRef] [PubMed]

(C) 2019 by the authors. Licensee MDPI, Basel, Switzerland. This article is an open access article distributed under the terms and conditions of the Creative Commons Attribution (CC BY) license (http://creativecommons.org/licenses/by/4.0/). 